
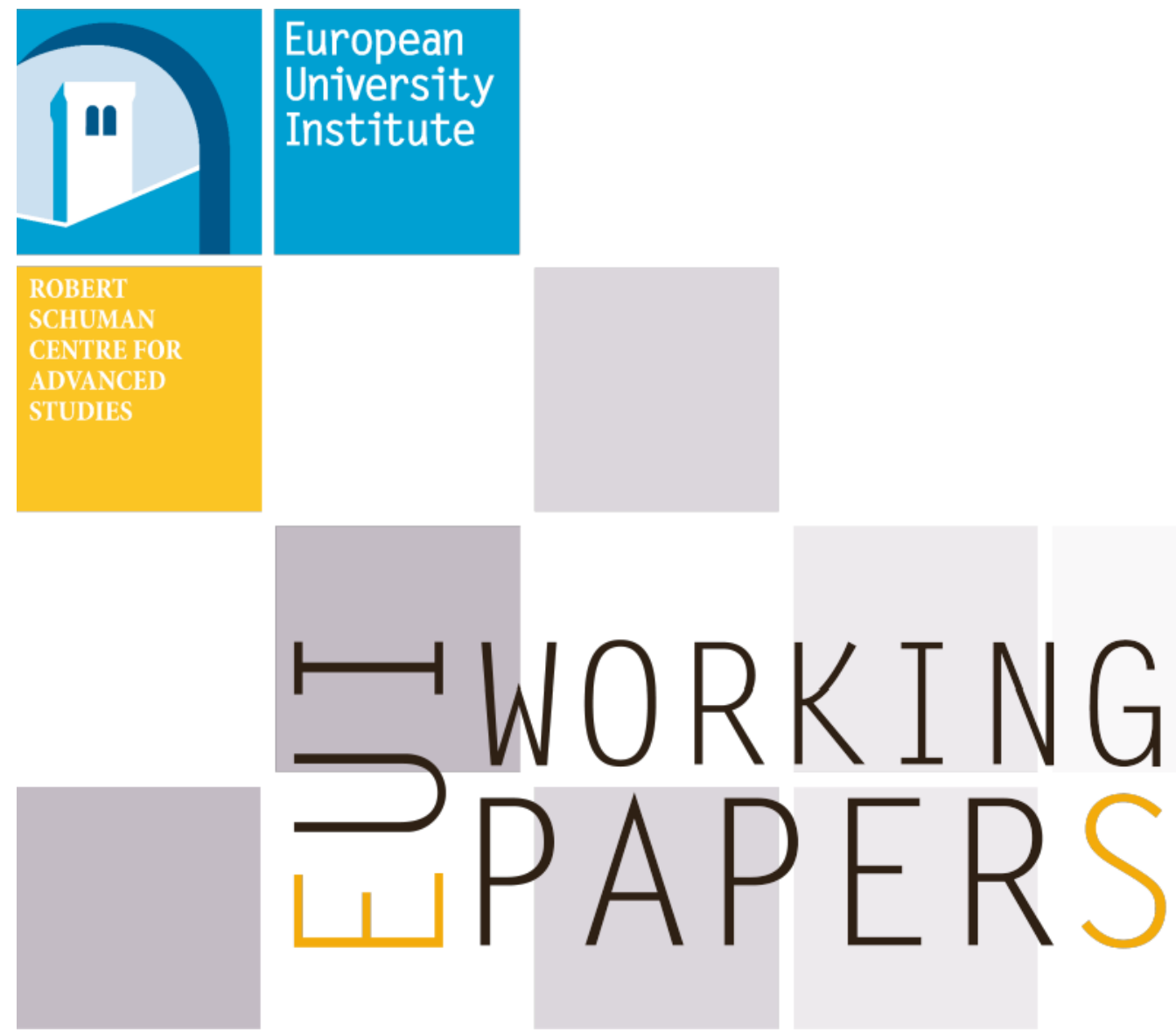

RSCAS 2016/26

Robert Schuman Centre for Advanced Studies Global Governance Programme-216

North African Countries and Firms in International Production Networks

Davide Del Prete, Giorgia Giovannetti and Enrico Marvasi 

European University Institute

Robert Schuman Centre for Advanced Studies

Global Governance Programme

North African Countries and Firms in International Production Networks

Davide Del Prete, Giorgia Giovannetti and Enrico Marvasi

EUI Working Paper RSCAS 2016/26 
This text may be downloaded only for personal research purposes. Additional reproduction for other purposes, whether in hard copies or electronically, requires the consent of the author(s), editor(s). If cited or quoted, reference should be made to the full name of the author(s), editor(s), the title, the working paper, or other series, the year and the publisher.

ISSN 1028-3625

(C) Davide Del Prete, Giorgia Giovannetti and Enrico Marvasi, 2016

Printed in Italy, April 2016

European University Institute

Badia Fiesolana

I - 50014 San Domenico di Fiesole (FI)

Italy

www.eui.eu/RSCAS/Publications/

www.eui.eu

cadmus.eui.eu 



\title{
North African Countries and Firms in International Production Networks
}

\author{
Davide Del Prete ${ }^{\dagger}$ \\ (Sapienza University of Rome)
}

\author{
Giorgia Giovannetti \\ (University of Firenze and EUI)
}

\author{
Enrico Marvasi \\ (University of Firenze)
}

April 2016

\begin{abstract}
This paper analyzes the participation of North African countries into international production networks and examines if/to what extent being part of a global value chain affects firms' performance. Using largely unexploited Input-Output data from UNCTAD-Eora, we describe regional and country GVC involvement. Results show that North African countries have not been able so far to fully integrate into international production networks. However, large part of their (low) trade is due to value added related activities, mainly in the upstream phases, and the importance of global linkages has been increasing over time. To better understand the impact of international fragmentation of production on competitiveness, we complement the above assessment with a firm-level analysis. We show that the performance of firms, measured by several indicators, is positively associated with both internationalization modes and GVC participation. These results confirm those of our sectoral analyses and are in line with existing anecdotical evidence. Enhancing GVC participation of North African countries is likely to substantially benefit firms, countries and the whole area. However, the ability to retain such benefits relies on specific characteristics, such as the level of human capital, trade logistics and the presence of trade barriers, thus leaving room for policy intervention.
\end{abstract}

Keywords: global value chains, firm heterogeneity, North Africa, competitiveness.

JEL codes: F14, F15, L23, L25, 055.

\footnotetext{
We would like to thank participants to the OECD workshop "Value chains: global or regional?" in Paris (April, 2015); Adam Storeygard and the partecipants to the CSAE conference in Oxford (March, 2016); Alessandro Borin and the partecipants to the ITSG workshop in Rome (December, 2015); Alessia Amighini and the partecipants to the '56th SIE conference in Naples (October, 2015); and at several seminars for useful comments. Usual disclaimers apply.

$\dagger$ Corresponding author. Mail to davide.delprete@uniroma1.it. Department of Economics and Social Sciences, Piazzale Aldo Moro, 5 - 00185 Rome - Italy.
} 


\section{Introduction}

In the last two decades technological progress, a sharp decrease in trade barriers and in transportation and information costs changed the way goods and services are produced and exchanged. The emrgence of the international fragmentation of production is rooted in the global "unbundling" of different stages of production previously performed in close proximity (Johnson and Noguera, 2012). The analysis of international trade is now typically taking place in the context of Global Value Chains (GVCs), a concept that encompasses the full range of activities required to bring a good or service to the final consumer, from the product design to the distribution (Cattaneo et al., 2010).

GVCs entail a vertical fragmentation of production process: parts and components are produced in different countries and then assembled either sequentially along the chain or in a final location (Del Prete and Rungi, 2015). The networks of involved firms are highly complex, spanning from manufacturing activities to logistics and transportation, as well as customs agents and other services (Baldwin and Venables, 2013).

Against this background, countries are no longer the single frame of analysis. In order to assess a country's degree of competitiveness and the impact of economic policies, it is crucial to take into account also the firm-level cross-border dimension of production processes. Firms not necessarily need to have the domestic capacity to perform all major production steps and the expertise to export, they can simply support the value chain as suppliers of intermediate inputs and act as subcontractors, even several levels down from the ultimate buyer (Humphrey and Schmitz, 2002).

Participation in a supply chain and cooperation within a network of upstream and downstream partners can enhance a firm's information flows and learning possibilities, introduce new business practices and more advanced technology, in turn enhancing growth. Hence, the reallocation of resources from less productive activities to new and more connected ones is crucial.

In the past two decades, several countries, especially in Asia, have been able to exploit these opportunities and enter global production networks. China, for instance, has integrated into GVCs by firstly specializing in the activities of final good assembly and was then capable of upgrading its participation by building a competitive supply base of intermediate goods and by enhancing the quality of its exports (Marvasi, 2013). Contrary to Asia, and China in particular, North Africa (NA) has not been able so far to intercept the main changes in trade patterns nor enter massively into production networks. But as China and other Asian countries move up the value chain, other countries need to become the next hub of labor intensive productions and expand technological sectors. Despite a relatively good geographic and logistic positioning, most North African firms, especially the smaller ones, have mainly remained "local", producing at home and for the domestic market. Their involvement in GVCs is still limited and mostly on low value added phases.

This paper describes if and to what extent North African countries have been able to enter GVCs and what are the possible benefits from a greater integration. It aims to narrow the divide between macro and micro evidence on value chains, by looking at both dimensions in a joint perspective. Firstly, it directly addresses the issue of participation in GVCs for North African countries, by employing a largely unexploited database from UNCTAD-Eora. To the best of our knowledge, this is the first attempt to directly focus on NA at a macro-level, due to lack of data from multi-region Input-Output tables used so far (e.g. WIOD among others).

Second, the paper complements the macro analysis investigating GVCs participation at the firmlevel. The existing literature is scant and mainly based on case studies. The paper fills the gap by providing an empirical micro assessment of GVC involvement and its role in driving firms' productivity. To this aim, we use the World Bank Enterprise Survey database.

The empirical analysis is performed on the years before the beginning of both the Great Recession and Arab Spring. The macro analysis refers to the period 1995-2007, while the firm-level analysis is applied to a 2007 cross-section of North African firms. Two main reasons motivate the choice of the period beside data availability. The first concerns macroeconomic conditions: studying the pre-2007 period keeps the possible shocks of the Great Recession out of the analysis. The second reason is idiosyncratic to North Africa, as the more recent years have been characterized by political instability and turmoil following the Arab Spring. While investigating the economic effects of those extreme events is of primary interest, this goes beyond the scope of this paper and is left for future research. 
The rest of the paper is organized as follows. Section 2 describes participation of North African countries and positioning along the value chain, using Input-Output tables and trade data. Section 3 investigates empirically the relationship between international activities and firm-level productivity. The Conclusions provide a joint reading of the micro and macro evidence and assess the scope for participation of North African countries in global value chains, discussing possible policies and their implications for competitiveness.

\section{Macro perspective - value added trade patterns}

As different stages of the same production process are now likely to be allocated to different countries, intermediate inputs cross borders multiple times and are then counted each time by gross trade flows. As a result, conventional trade statistics become increasingly misleading as a measure of value produced by any particular country. However, recent improvements in Input-Output (I-O) metrics allow us to measure the sources and destinations of value-added trade (Koopman et al., 2011).

In this section, exploiting the UNCTAD-Eora GVC database, we analyze the GVC participation and position of NA countries/sectors. We derive North Africa value added trade data from the Eora global multi-region I-O (MRIO) table, that brings together a variety of primary data sources including national I-O tables and main aggregates data from national statistical offices and combines these primary data sources into a balanced global MRIO, using interpolation and estimation in some places to provide a contiguous, continuous dataset for the period 1990-2010 (Lenzen et al., 2012, 2013).

In order to compute the different value added components, we rely on the Koopman et al. (2011) decomposition: the foreign value added share (FVA) indicates the share of a country's exports that consist of inputs produced in other countries and thus does not add to the GDP of the country of interest. It captures the extent of GVC participation for downstream firms and industries. The 'indirect value added exports' (DVX), i.e. the share of a country's value added exports embodied as intermediate inputs in other countries' exports, represents the contribution of the domestic sector to the exports of other countries, thus indicating the extent of GVC participation for relatively upstream sectors. Summing the FVA and the DVX components of a single country/area, we can get a comprehensive description of GVC participation (for more details on this procedure see the Appendix).

To validate our database, we can rely on few references since, to the best of our knowledge, there is no similar database covering input-output data for 187 countries around the world. Hence, we employ the above methodology to compute the FVA component from the World Input Output Database (WIOD) and we retrieve the same figure directly from the OECD-WTO Trade in Value Added (TiVA) database (Timmer et al., 2015; OECD and WTO, 2012). The correlations between the 1995 foreign value added share, as computed from the EORA database and matched against the same country figures provided by WIOD and TiVA are respectively .88 and .76 .

\section{$2.1 \quad$ GVCs country analysis}

We look at the North African (NA) GVC involvement from two different perspectives. First, by analyzing value added components in absolute terms, we are able to get a clear picture of the actual volume of GVC trade. Second, as a shares of total export, GVC components also provide information on the importance of fragmentation of production to the creation of value added for each country's exports. Hence, we firstly compare NA with other major exporters in a trade volume perspective, then we investigate the role of GVCs for NA exports.

In order to give a comprehensive picture of the phenomenon, Figure $1^{1}$ encompasses both per-

\footnotetext{
${ }^{1}$ In the following figures, CHN stands for China; IND: India; LAC encompasses Argentina, Guyana, Chile, Suriname, Bolivia, Ecuador, Colombia, Brazil, Uruguay, Paraguay, Peruc and Venezuela; NAFTA: Mexico, USA and Canada; EU27: Austria, Belgium, Bulgaria, Cyprus, Czech Republic, Denmark, Estonia, Finland, France, Germany, Greece, Hungary, Ireland, Italy, Latvia, Lithuania, Luxembourg, Malta, Netherlands, Poland, Portugal, Romania, Sierra Leone, Slovakia, Spain, Sweden and UK; ASEAN: Brunei, Cambodia, Indonesia, Laos, Malaysia, Myanmar, Philippines, Singapore, Thailand and Viet Nam; MEAST: Bahrain, Cyprus, Egypt, Gaza Strip, Iran, Iraq, Israel, Jordan, Kuwait, Lebanon, Oman, Qatar, Saudi Arabia, Syria, Turkey, UAE and Yemen; OCEANIA: Australia, Fiji, New Zealand, Papua New Guinea, Samoa and Vanuatu; NA: Algeria (DZA), Egypt (EGY), Libya (LBY), Morocco (MAR) and Tunisia (TUN); SSA: Angola, Benin, Botswana, Burkina Faso, Burundi, Cameroon, Cape Verde, Central African Republic, Chad, Congo, Cote
} 
spectives, as it shows the 2007 overall GVC participation (as shares), for some main countries/areas (Figure 1a), and (selected) North African countries (Figure 1b), together with export volumes, i.e. by definition, the sum of foreign value added and domestic value added in volumes. Not surprisingly, export volumes are mainly concentrated in developed countries (EU about 7 trillion USD which corresponds to a $42 \%$ world export share and NAFTA 19\%) and China 7\%. With a share of less than $1 \%$ of world export, NA plays a very marginal role in world trade. Turning to the individual NA countries figure, Algeria and Libya, given the composition of their production, biased towards energy, present the highest exports values, with about 45 bln and 25 bln of USD in 2007.

Figure 1: FVA, DVX and Exports in 2007

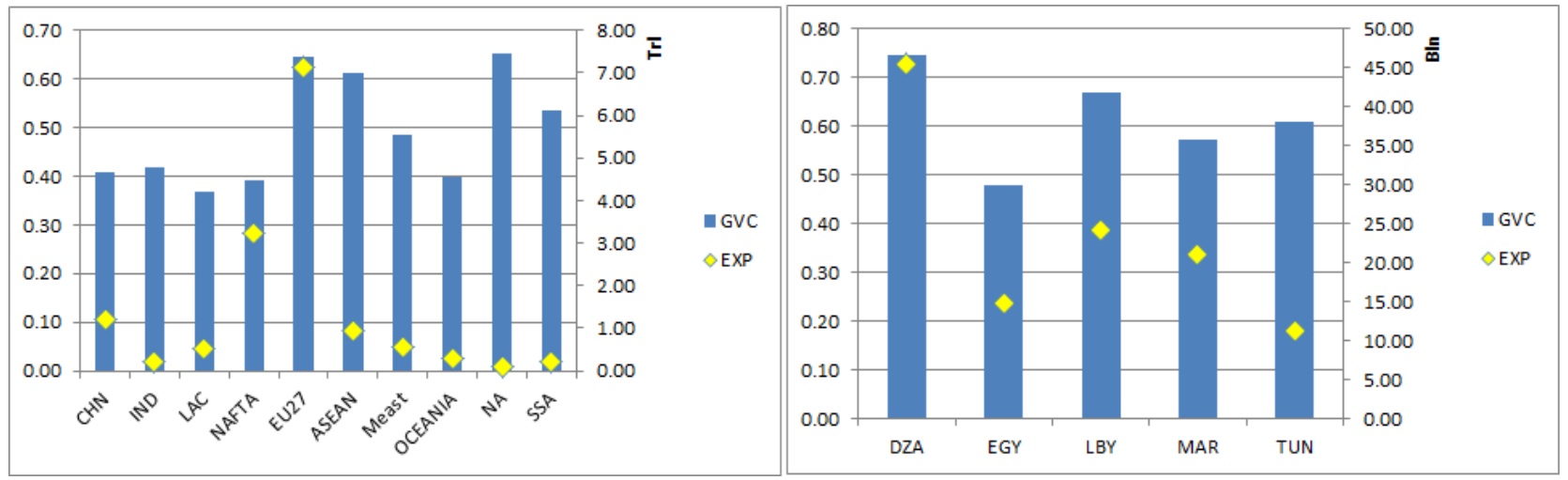

Source: Authors' elaboration based on UNCTAD/EORA GVC Database.

This evidence is also confirmed by considering foreign value added and the value of exports of intermediates in value added exports of other countries respectively for each region and for North African individual countries. Figures 2 and 3, focusing on GVC trade volumes of developing areas ${ }^{2}$, confirm that North Africa has not yet been able to enter GVCs and play a significant role at the world level, making up about $1 \%$ of foreign value added and exports of other countries' value added exports. Despite this, a good deal of heterogeneity emerges when we look at individual countries: Algeria and Morocco have the highest foreign value added values (Figure 2b) while Algeria and Libya the highest values of exports of other countries' value added exports (Figure 3b). This suggests that specialization matters.

Figure 1 above also shows the total levels of GVC participation, i.e. the total sum of FVA in exports and DVX in exports. The fact that advanced ${ }^{3}$ and ASEAN countries are heavily integrated in GVCs is hardly surprising. What is more interesting, and in line with the results of Foster-McGregor et al. (2015), is that North Africa has some of the highest rates of GVC participation, matching the levels found in Europe (65\% in 2007). In particular, Algeria presents the highest GVC participation rate, followed by Libya and Tunisia, respectively with $74 \%, 67 \%$ and $61 \%$ rate.

Figure 4 presents the evolution of the phenomenon over time, as it compares the GVC participation in 1995 and 2007. Figure 4a indicates that not surpsrisingly GVC participation has been increasing in most regions, from around $50 \%$ to $54 \%$ worldwide. The growth rate of GVC participation in NA has also been almost the double to that of all countries, with GVC participation increasing by $14 \%$ for North Africa and 8\% for all countries over the period 1995-2007 (Figure 4a). Figure 4b details the

d'Ivoire, DR Congo, Djibouti, Eritrea, Ethiopia, Gabon, Gambia, Ghana, Guinea, Kenya, Lesotho, Liberia, Madagascar, Malawi, Mali, Mauritania, Mauritius, Mozambique, Namibia, Niger, Nigeria, Rwanda, Sao Tome and Principe, Senegal, Seychelles, Sierra Leone, Somalia, South Africa, Swaziland, Tanzania, Togo, Uganda, Zambia and Zimbabwe.

${ }^{2}$ Here we exclude EU27 and NAFTA, since they operate at a higher scale. If included, the graph would not allow to see heterogeneity among other countries/areas.

${ }^{3}$ Note that considering the individual countries separately, we are likely to inflate the extent of GVC participation of the EU27 relative to other large single countries, such as the China and India. 
Figure 2: Foreign Value Added volume (excluding EU27 and NAFTA)
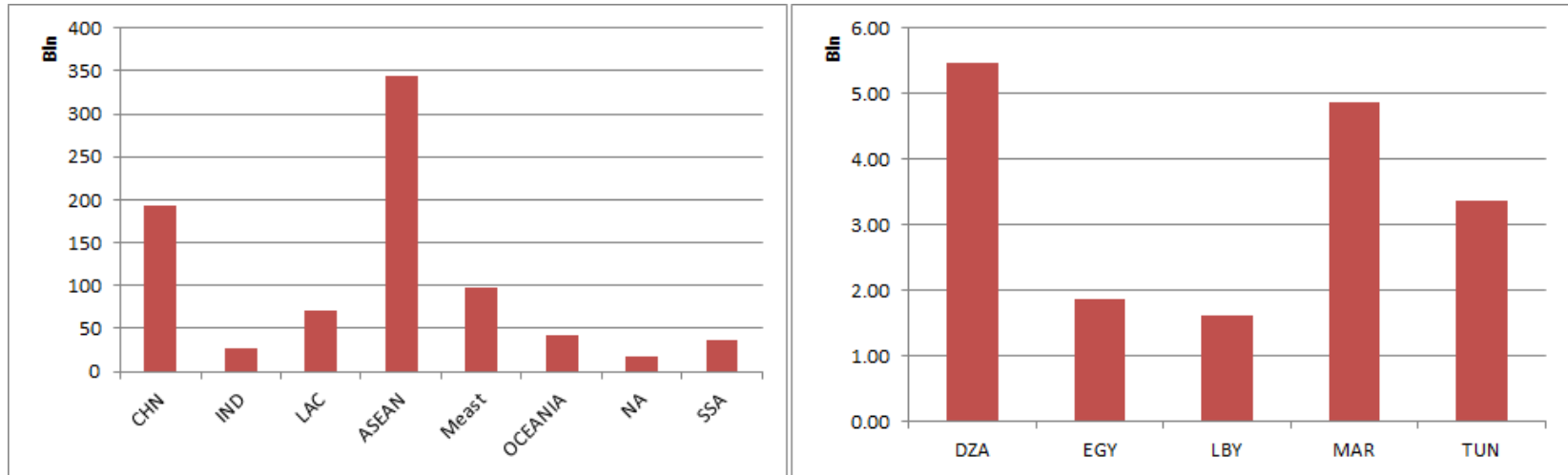

Source: Authors' elaboration based on UNCTAD/EORA GVC Database.

Figure 3: Indirect Value Added volume (excluding EU27 and NAFTA)
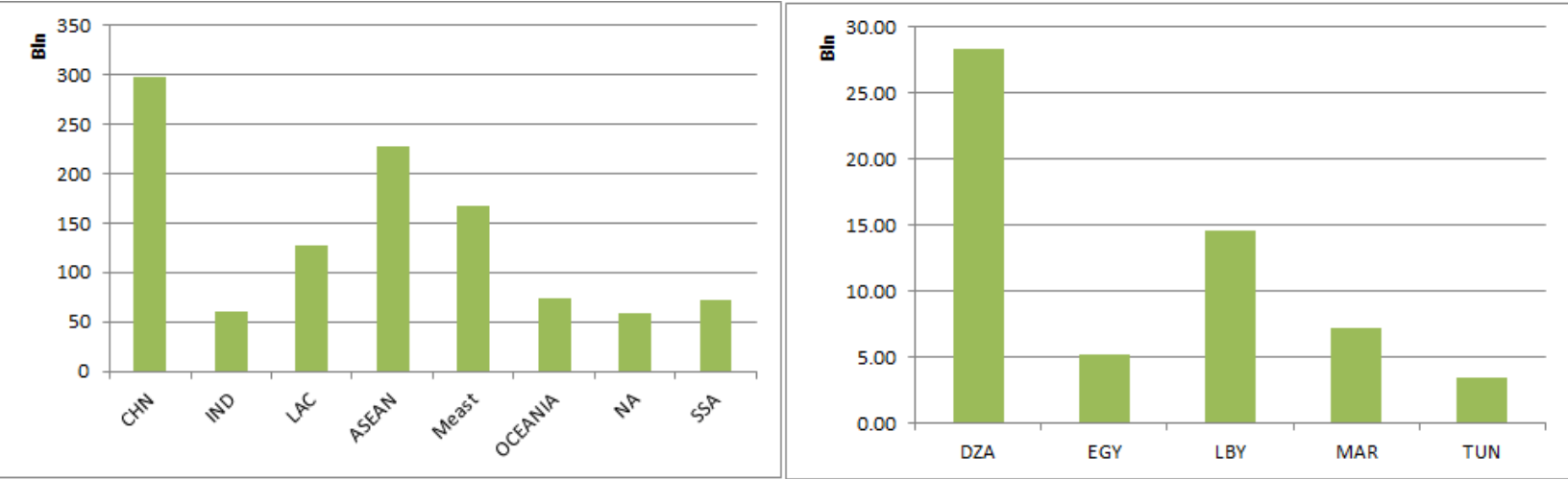

Source: Authors' elaboration based on UNCTAD/EORA GVC Database.

differences between NA countries and shows that, between 1995 and 2007, Libya GVC participation grew by $17 \%$, while that of Algeria and Morocco by $14 \%$.

Following Koopman et al. (2011) approach, in Figure 5 and 6 we split total GVC participation into the FVA and DVX components, i.e. foreign value added and the value of exports of intermediates in value added exports of other countries as shares of total exports. As mentioned above, the former indicates the extent to which a country's exports are dependent on imported content, the so-called backward integration. It is therefore likely to be higher if a country (or sector) is involved in downstream production. Conversely, the DVX measure is likely to be higher for countries (and sectors) involved in upstream production, with output and exports of that country feeding into the production and exports of downstream producers (i.e. forward integration). The analysis of backward and forward integration can provide hints on where within a GVC a particular country is. While upstream stages are associated with the production of knowledge assets at the beginning of the value chain, in a developing country context, where rates of innovation are low, it is more likely associated with the production of raw materials and other basic inputs, which may have little scope for upgrading (Foster-McGregor et al., 2015).

At the global level, the average FVA is approximately 30\% in 2007 (Figure 5a). That means, roughly, that around 5 trillion of the 17 trillion in 2007 world exports of goods and services has been 
Figure 4: GVC participation

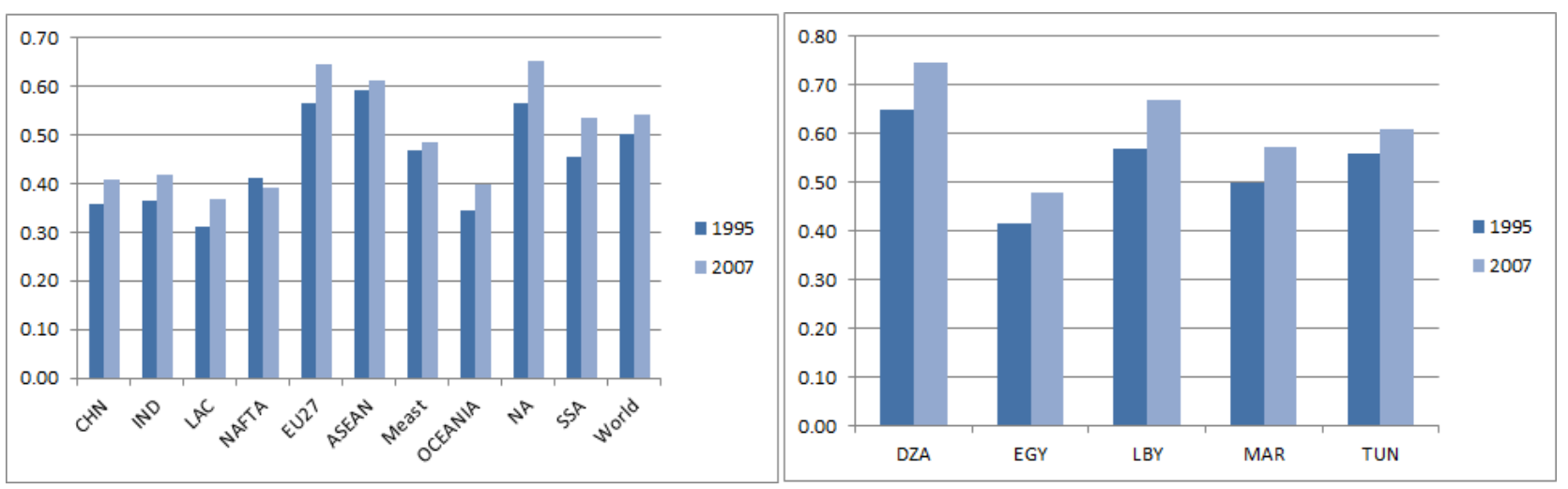

Source: Authors' elaboration based on UNCTAD/EORA GVC Database.

contributed by foreign countries for further exports and is thus "double counted" in global trade. The remaining 12 trillion is the actual value added contribution of trade to the global economy. FVA has tended to rise over time for all countries, though the increase has been largely driven by the advanced countries. Overall, foreign value added increased by around 10\% between 1995 and 2007 with large increases occurring in EU27 19\% and China 33\%. For other developing regions a decline in FVA was observed between 1995 and 2007 with the largest declines occurred for the ASEAN (by 10\%) and Middle East (5\%) regions.

In 1995 foreign value added in NA was $13 \%$ and increased to $15 \%$ in 2007, resulting in a $15 \%$ growth rate (Figure 5a). At a higher detail, Tunisia (30\%) and Morocco (23\%) present the highest FVA in the region (Figure 5b). These results suggest that along with other developing regions, North Africa has struggled to become increasingly engaged in downstream production within GVCs.

Figure 5: Foreign Value Added component (FVA)

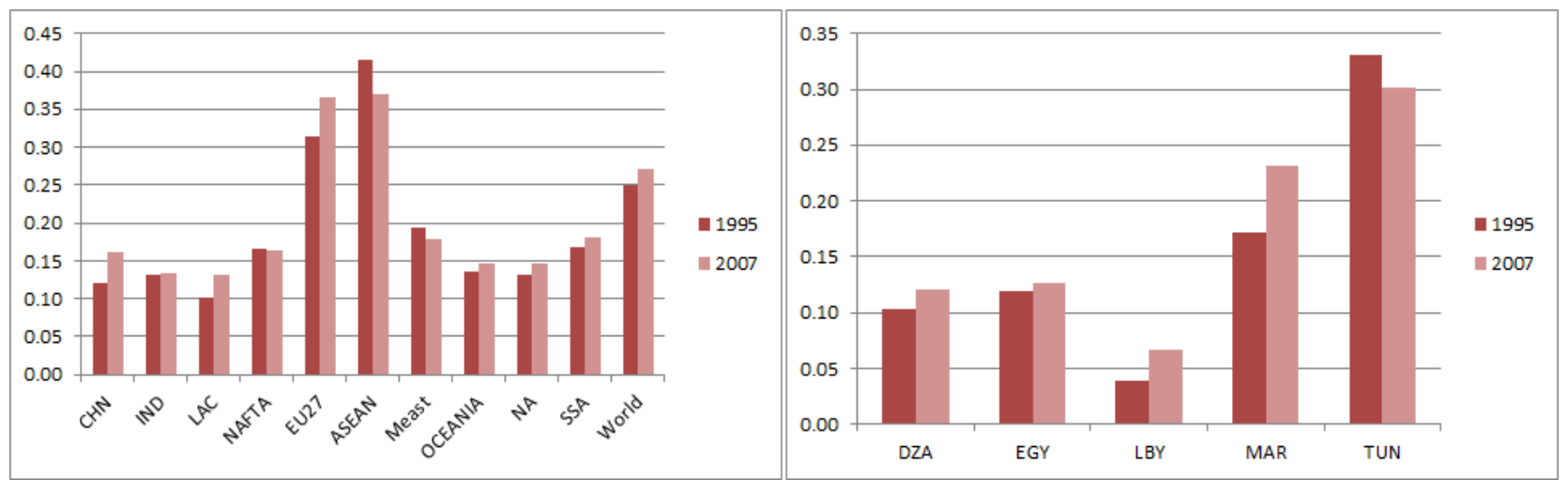

Source: Authors' elaboration based on UNCTAD/EORA GVC Database.

Figure 6 reports similar figures for DVX and suggests an increase in the indirect value added of exports for all regions. In 2007, North Africa has the highest DVX share (50\%). The region also shows the largest increase in the DVX measure between 1995 and 2007, with an increasing by 16\%. Large growth rates also occurred in SSA countries (21\%) and ASEAN (33\%) countries. Not surprisingly, increases were much larger for developing countries than for advanced countries, already integrated at the beginning of the period.

The large values for the DVX variable combined with the relatively small values for the FVA 
Figure 6: Indirect Value Added component (DVX)

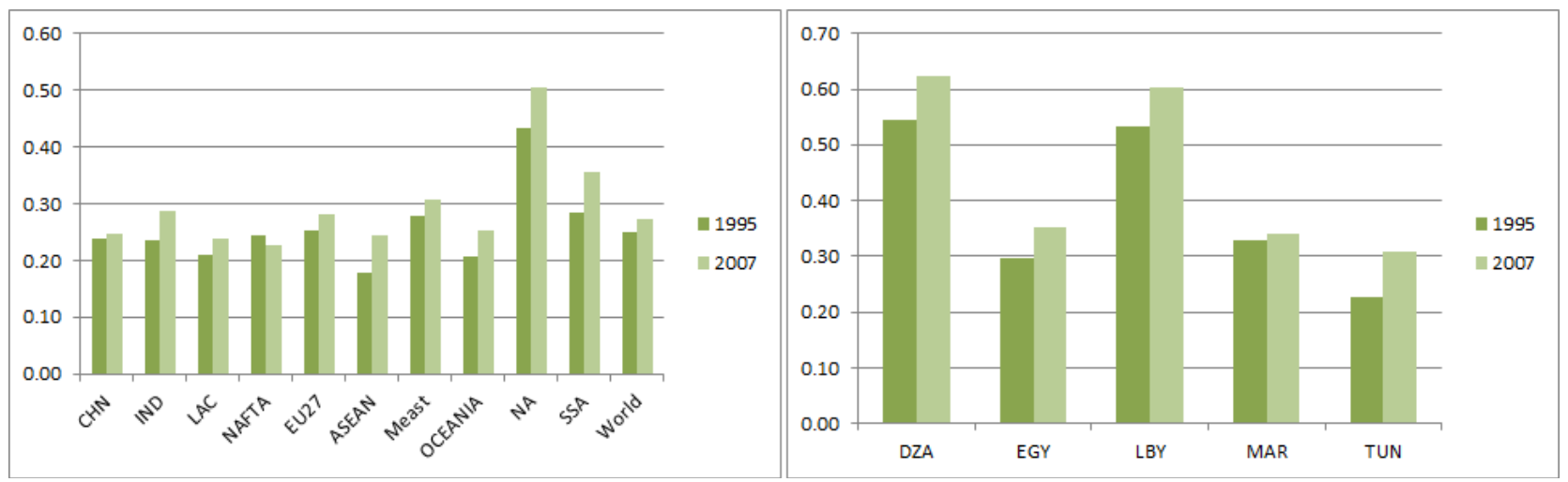

Source: Authors' elaboration based on UNCTAD/EORA GVC Database.

variable in the case of NA further reinforces the view that it has struggled in breaking into downstream production and that much of its involvement in GVCs is in upstream productions (e.g. natural resource and simple manufacturing). Indeed if we consider the share of total GVC participation that is due to the DVX measure, we find that it accounts for $77 \%$ in 2007, a fact that highlights the importance of forward integration in the region. However there is evidence of some country heterogeneity. While Algeria and Libya follow this pattern, Morocco and Tunisia show a greater share of FVA in total GVC participation, with a $40 \%$ and $49 \%$ of share respectively, suggesting a slightly more downstream position (Figure 6a,b) and with some potential to better integrate in higher value-added phases.

To sum up, NA is a very marginal player of GVC-related trade and has not yet been able to exploit the opportunities coming from the emergence of global production networks. But, while NA plays a secondary role for the actual volumes of value added related activities at the world level, GVCs are found to be of primary importance for NA trade: participation in the international fragmentation of production has been steadily increasing in the last decades and the share of NA exports due to value added trade is now in line with that of other major areas. The overall figure, however, hides an important fact: NA takes part in GVCs by contributing mainly to the upstream phases, being confined to low value added stages of production, with some exceptions.

\subsection{North Africa and GVCs: sectoral analysis}

The heterogeneous involvement of North African countries in GVCs depends on the productive structure of the different economies, their endowments as well as some characteristics such as education level and quality, presence of tax benefits, technological parks etc.

In what follows we analyze the sectoral dimension of the phenomenon, linking it with some practical examples of GVC participation in North Africa. Although the area is mainly involved in stages of the production far from the final consumers, for some countries there is evidence of downstream integration. Here the possibilities of upgrading are potentially stronger, and as such it is crucial to understand the sectoral specialization of their economies.

We compute the sectoral contributions to the measures of GVC participation described above for NA region and for the set of NA countries. The sum across the sectors therefore will be equal to the value of total NA GVC participation reported in Figure 1. To this aim we present in Figure 7 the contribution of each of 25 ISIC-type sectors ${ }^{4}$ to involvement in GVCs as measured by the sum of FVA and DVX measures.

Figure 7 shows that the primary and upstream sectors of Mining and Quarrying, Financial Intermediation, and Petroleum and Chemicals make up the vast majority of NA GVC participation (32\%).

\footnotetext{
${ }^{4}$ See Table Appendix for a correspondence table between the 25 EORA sectors and the ISIC-Rev 3 classification.
} 
Figure 7: North Africa Sectoral GVC Participation (FVA + DVX) 2007

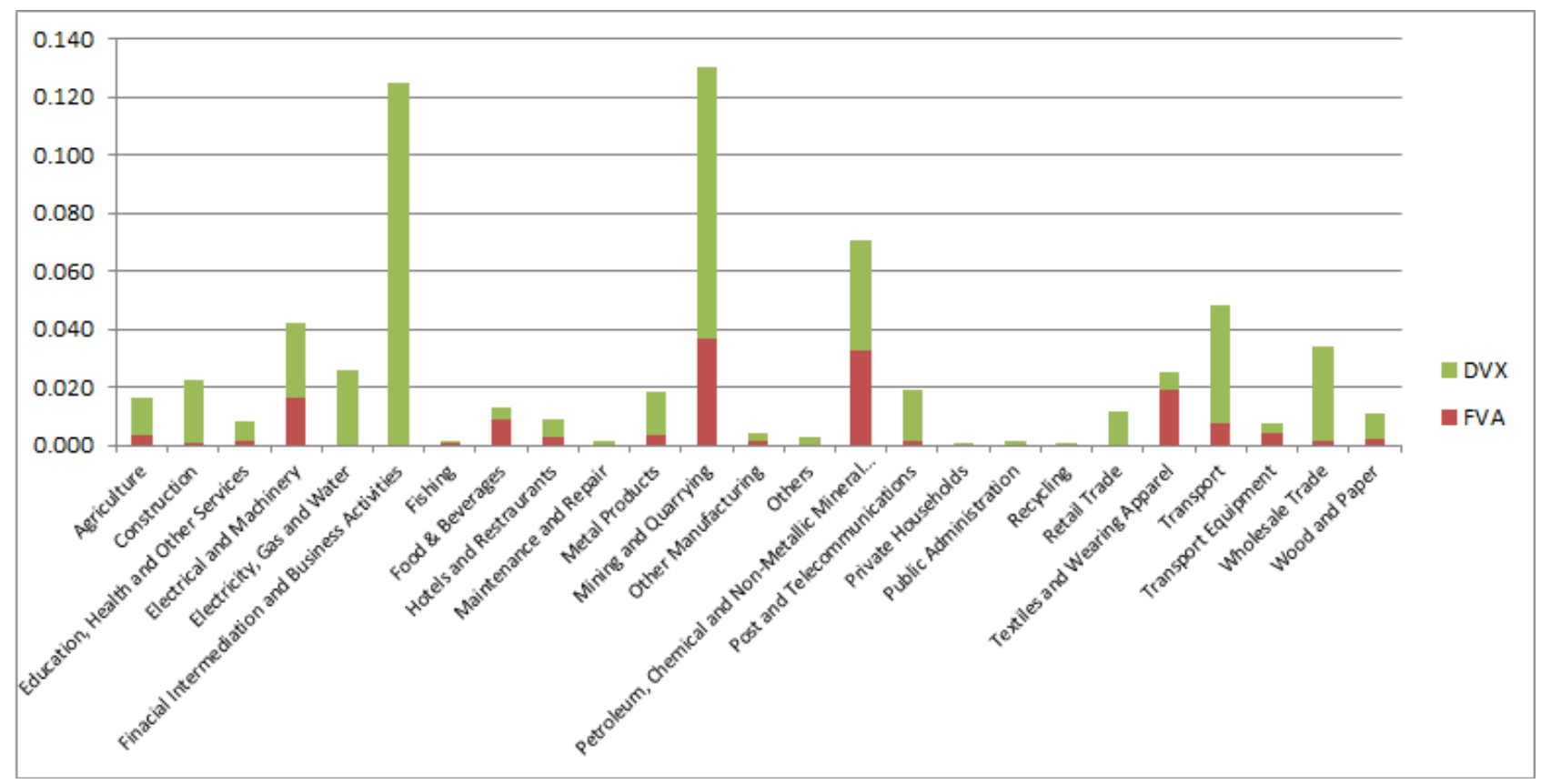

Source: Authors' elaboration based on UNCTAD/EORA GVC Database.

However, when considering its decomposition into backward (i.e. FVA) and forward (i.e. DVX) integration, we find that Mining \& Quarrying and Petroleum and Chemicals continue to be significant, along with Textiles and Apparel, and Electrical and Machinery, while Financial Intermediation no longer makes an important contribution.

This result considers the region as a whole, but as mantained above, countries are fairly heterogeneous. In what follows, we will focus on Morocco and Egypt, for which anecdotal evidence of value chain participation has been reported ${ }^{5}$ (AfDB et al., 2014).

Figure 8 shows that Morocco is mostly involved in Electrical and Machinery and Textiles and Wearing Apparel industries. The country is more prone to participate in the downstream phases of these productions as the relatively high shares of FVA show. Morocco is indeed "a rear base for the French aerospace industry". All Airbus aircraft machineries delivered worldwide fly with parts manufactured by the Moroccan aeronautics industry, which employs 10,000 people and plans to double the number of companies in the sector by 2020 with 20,000 jobs into the bargain. ${ }^{6}$ The development of the aeronautics sector is a very promising global value chain, which relies on a pool of skilled human resources. With $100 \%$ of its production aimed at exports, the Moroccan aeronautics sector includes nearly 100 companies of international scope involved in activities covering production, services and engineering. EADS, Boeing, Safran, Ratier Figeac and, more recently, Eaton and Hexcel, are all present in Morocco.

The Moroccan garment industry is a key supplier for fast fashion supply chains, such as Zara, also thanks to its proximity to the EU market. The latter is a crucial driver of fast supply chains because of the speed and responsiveness of suppliers to meet changes in demand effectively. The Moroccan textile industry association has been able also to create over time a sector-led code of conduct and social label called Fibre Citoyenne, which the fashion retailers find attractive, leading to a successful upgrade into global fashion value chains. Their workers shared in the gains from economic upgrading, improving skills and benefiting from measurably improved standards (AfDB et al., 2014).

\footnotetext{
${ }^{5}$ For sectoral analyses of Algeria, Libya and Tunisia see Table Appendix.

${ }^{6}$ These numbers appeared in the news in 2015. See, for instance, the article "Morocco's fledgling aeronautics sector
} 
Figure 8: Morocco Sectoral GVC Participation (FVA + DVX) 2007

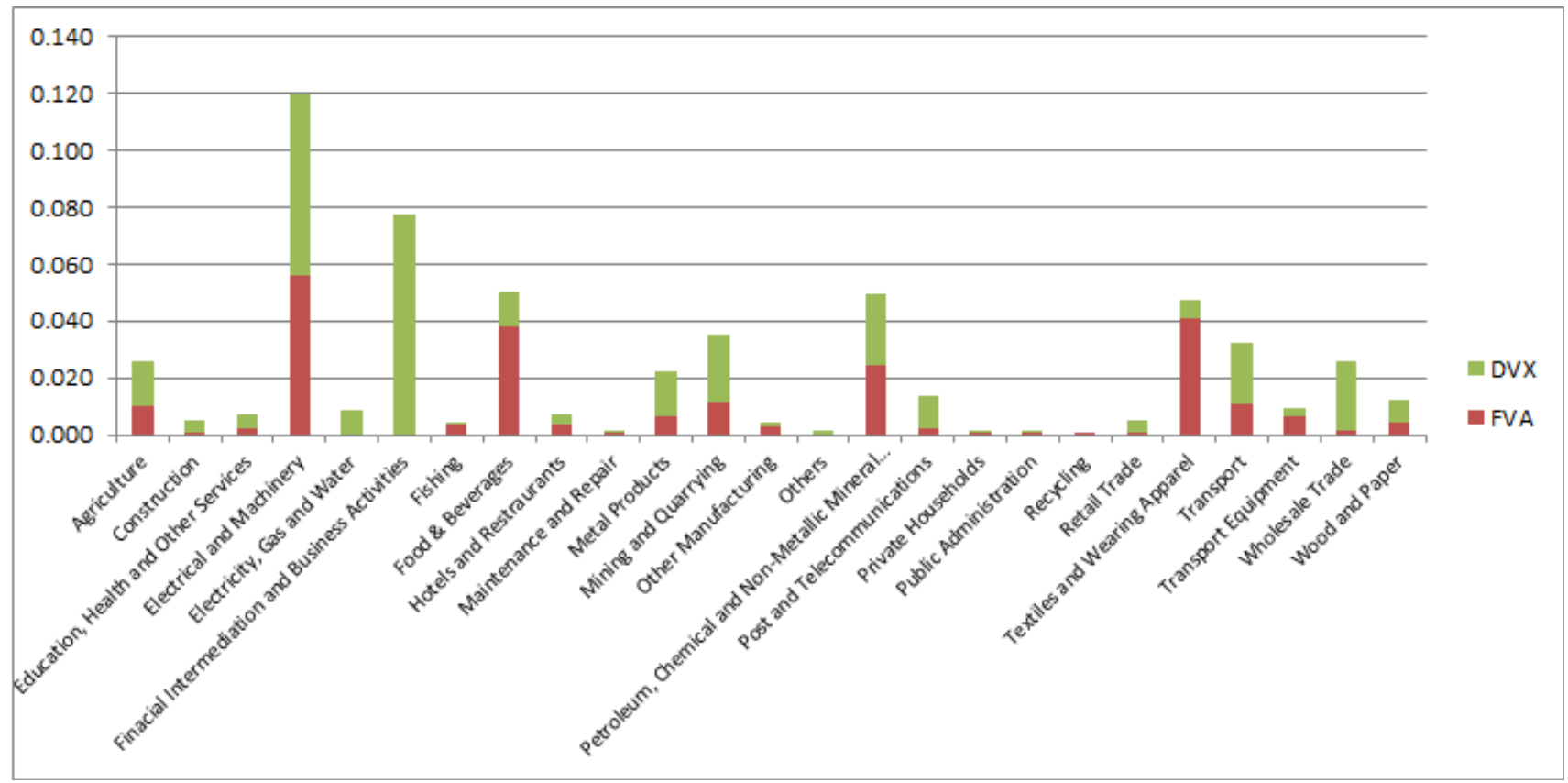

Source: Authors' elaboration based on UNCTAD/EORA GVC Database.

This anecdotal evidence is supported by our data and further reinforced by looking at trade in intermediates, of which the analysis represents another tool to roughly detect participation in GVC related activities. As of today about $60 \%$ of global trade consists of intermediates and services, incorporated at different stages of production (UNCTAD, 2013). NA trade in intermediates was about $50 \%$ in 2012, with Egypt showing the highest intermediates export share (57\%) followed by Morocco (53\%) while Tunisia, on the other hand, shows the highest intermediate share for imports (59\%) (Figure 9a).

Figure 9b shows that Morocco is highly involved in the aerospace value chain, by importing intermediates and exporting components of the aircraft. In the textile sector, Morocco is instead very close to the final consumers. It mainly imports intermediate goods and, once processed, exports final goods.

Two other Moroccan industries are involved in international production networks in automotive and phosphates. The automotive sector has been able to enter the Renault-Nissan value chain in Tangiers in 2012, with an annual production capacity of 340,000 vehicles, $90 \%$ of which are intended for export, in particular to Europe. The automotive chain is interesting since it started with a large investment of the Renault group which then resulted in a policy of local integration; it aimed at increasing the number of components that are locally sourced, thanks to savings achieved through lower logistics costs. Second, the phosphate industry, that has finally positioned itself in all parts of the value chain from the production of fertilizer to that of phosphoric acid as well as derivative products.

If Morocco is at the forefront, also Egypt is an interesting case to single out. Microsoft has outsourced in Egypt services needed to complement its final products. Traditional IT Services (ITS), such as software installation and testing and IT Enabled Services (ITES), such as call centers, are by far the largest contribution of SMEs and not just packaged software and hardware. The call centers development in Egypt covers from very simple to complex operations, such as marketing, sales, and business and information technology (IT) consulting. Accordingly, the Financial Intermediation 
Figure 9: Trade in intermediates in NA countries and Morocco

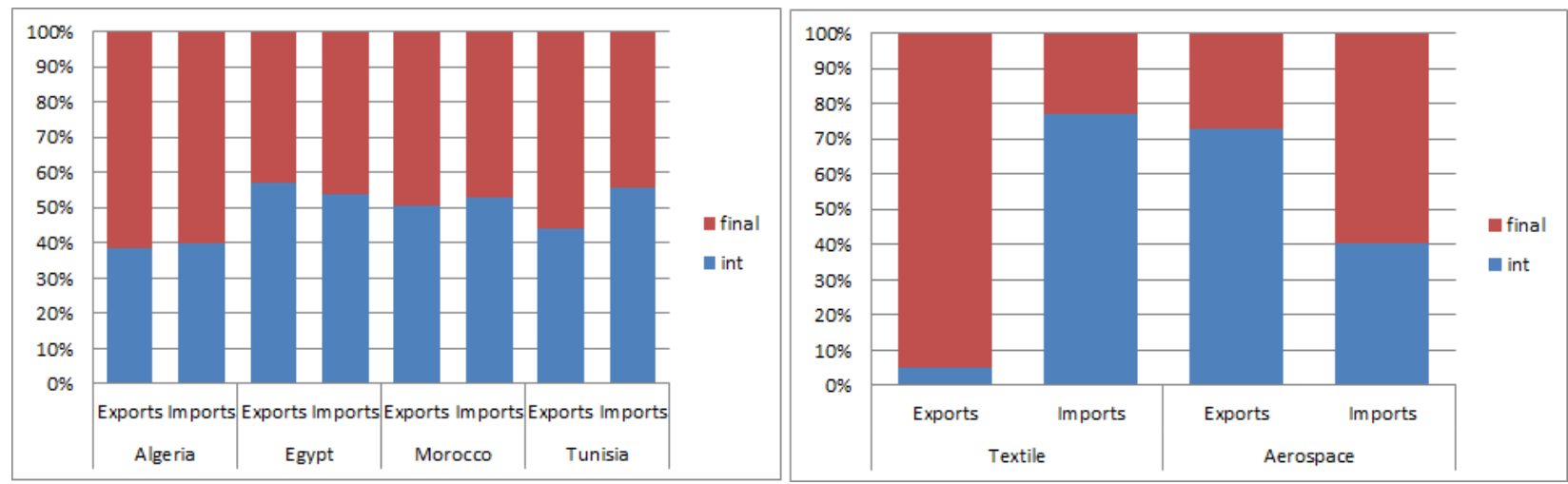

Source: Authors' elaboration based on STAN Bilateral Trade in Goods by Industry and End-use (BTDIxE), ISIC Rev.4.

and Business Activities sector actively participates in the international fragmentation of production, though the bulk of the country involvement is due to the Petroleum and Chemicals industry (Figure 10). Of course also Textiles are participating in GVC.

Figure 10: Egypt Sectoral GVC Participation (FVA + DVX) 2007

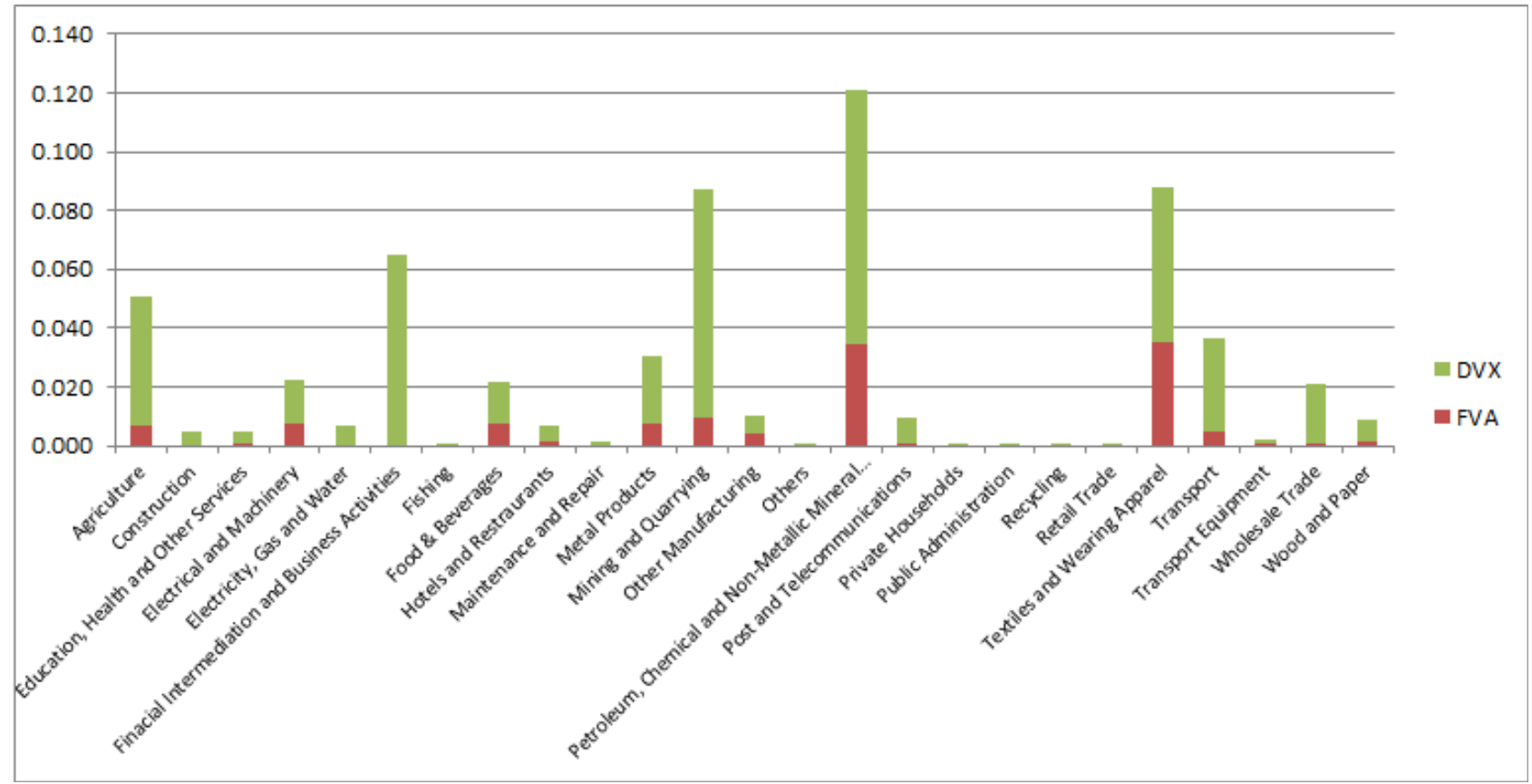

Source: Authors' elaboration based on UNCTAD/EORA GVC Database.

\section{Micro perspective - firms in GVCs}

The emphasis on international fragmentation of production and GVCs has contributed to shift attention to firms. Thanks to the splitting into single tasks, firms can now specialize in a particular stage of the chain and also internationalize despite, for instance, a small size. There is a growing debate 
on the role and the upgrading processes of the intermediate firms (Gereffi, 1994; Alcacer and Oxley, 2014). Agostino et al. (2015) and Giovannetti et al. (2015) argue that joining international supply chains may trigger an increase in productivity and competitiveness for small and less productive firms, by providing incentives and opportunities to upgrade their technical capabilities or just provide the specific task required in a value chain.

In this section, we describe a micro-level evidence on GVCs participation and its possible effects on the performance of firms. We exploit a subset of the original World Bank Enterprise Survey database. ${ }^{7}$ The available surveys provide information on the characteristics of firms across various dimensions, including size, ownership, trading status, and performance, and collects data for 930 manufacturing firms. For two NA countries, Egypt and Morocco, data are available for the years 2004 and 2007, which makes our analysis comparable with the one at the sectoral level.

The main descriptive statistics for the variables employed in the empirical analysis are reported in Table $1^{8}$.

Table 1: Summary Statistics

\begin{tabular}{lrrrrr}
\hline Variable & Obs & \multicolumn{2}{c}{ Mean Std. Dev. } & Min & Max \\
\hline Sales per empl. (ln) & 1825 & 8.98 & 1.58 & 2.27 & 16.64 \\
VA per empl. (ln) & 1764 & 8.57 & 1.55 & 1.33 & 16.64 \\
TFP (ln) & 1731 & 9.92 & 1.64 & 3.02 & 16.95 \\
Employment (ln) & 1858 & 3.79 & 1.36 & 1.79 & 9.48 \\
Exporter & 1860 & 0.06 & 0.24 & 0.00 & 1.00 \\
Importer & 1860 & 0.18 & 0.38 & 0.00 & 1.00 \\
Twoway trader & 1860 & 0.21 & 0.41 & 0.00 & 1.00 \\
GVC & 1836 & 0.10 & 0.30 & 0.00 & 1.00 \\
FDI & 1860 & 0.08 & 0.26 & 0.00 & 1.00 \\
Human capital & 1848 & 0.57 & 0.29 & 0.00 & 1.00 \\
Capital intensity (ln) & 1808 & 3.67 & 3.53 & -4.56 & 13.65 \\
Age & 1854 & 21.57 & 15.46 & 0.00 & 111.00 \\
\hline
\end{tabular}

Firms are characterized by different modes of internationalization, depending on the complexity of their links with other domestic or foreign firms. About $45 \%$ of firms in the area, with some differences between countries, are direct traders, mainly divided between twoway traders and pure importers. Overall, the most frequent internationalization mode involves importing, as $39 \%$ of firms buy products from aborad, that is almost $87 \%$ of international traders. Interestingly and possibly related to GVCs, the share of two-way traders (21\%) is larger than that of pure exporters (only 6\%), suggesting that firms may be indeed involved in value added trade related activities.

As expected, the share of traders tends to increase with the size of firms, as shown in Figure 11. This confirms a typical finding of the heterogeneous firms literature, where internationalized and large firms perform relatively better, thanks to their propensity to reach farther and more productive markets.

Figure 11 also shows that, not surprisingly, larger firms also have a higher probability of being both foreign owned and internationally quality certified.

Quality certifications guarantee and signal the ability of the firm to meet the international standards typically required in vertically fragmented production processes (Beghin et al., 2015). Firms operating in GVC need a high level of coordination along the chain, given the complexity of buyersupplier relations which implies the exchange of customized inputs. Against this background, international standards and quality certifications can play a key role in identifying involvement in international supply chains. Building on this idea, we use the presence of certifications among traders as a proxy

\footnotetext{
${ }^{7}$ We consider the same countries studied at the macro and sectoral level for coherence.

${ }^{8}$ We define internationalization modes as mutually exclusive: exporters are defined as firms that make more than $10 \%$ of their total sales abroad; exporters and importers refer to firms performing only one-way trade, while firms both importing and exporting are captured by the two-way dummy. Inward FDI is a dummy for firms with a share of foreign ownership above 10\%. Size is measured as the number of employees. Human capital is the ratio of skilled workers to total number of workers. Capital intensity is capital (machinery and land) over total number of workers.
} 
Figure 11: Shares of traders, certified firms and foreign owned firms by size class.

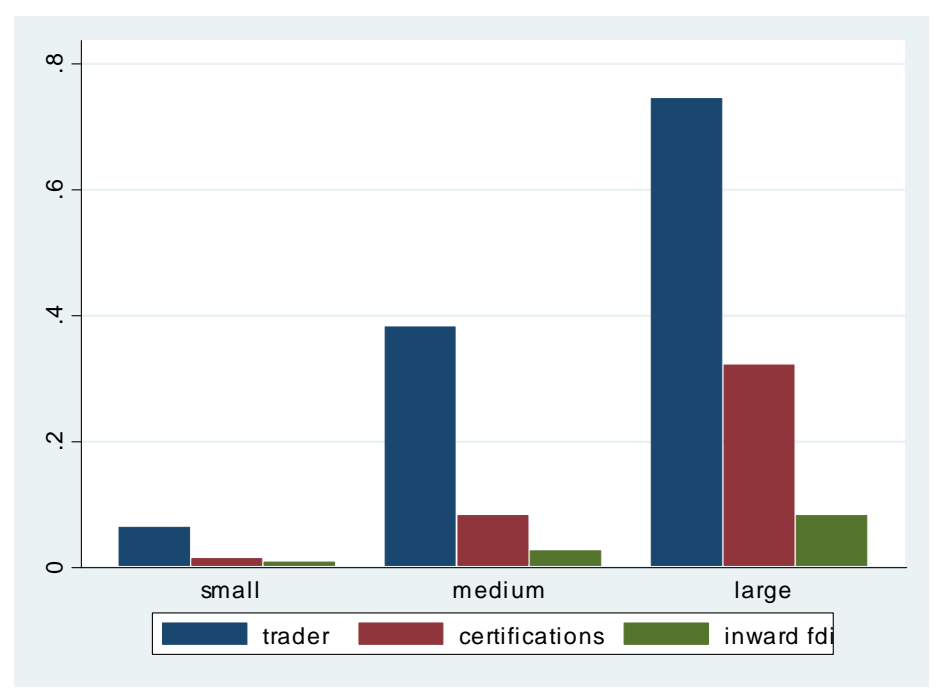

Note: small 5-19, medium 20-99, large from 100 employees

for GVC participation. ${ }^{9}$

As expected, summary statistics show that the share of internationalized firms is always higher among certified firms (Table 2). On the one hand, quality certifications tend to be strongly associated with internationalization, as $84 \%$ of certified firms are also international traders. On the other hand, certified firms are only $22 \%$ among traders (Table 3). Overall, almost all certified firms are also internationalized, although certifications seem to capture a specific feature characterizing only some of the traders.

Table 2: Shares of firms by certification and internationalization mode.

\begin{tabular}{lrrrrr}
\hline & Exporter & Importer & Twoway & FDI & Domestic \\
\hline Not certified & 0.05 & 0.15 & 0.19 & 0.06 & 0.61 \\
Certified & 0.16 & 0.34 & 0.34 & 0.20 & 0.16 \\
Total & 0.06 & 0.17 & 0.21 & 0.07 & 0.56 \\
\hline
\end{tabular}

Table 3: Shares of traders and certified firms.

\begin{tabular}{lrrr}
\hline & Domestic & Trader & Total \\
\hline Not certified & 61.0 & 39.0 & 100 \\
Certified & 16.1 & 83.9 & 100 \\
Total & 55.8 & 44.2 & 100 \\
\hline & & & \\
Not ce rtified & 96.7 & 78.2 & 88.5 \\
Certified & 3.3 & 21.8 & 11.5 \\
Total & 100 & 100 & 100 \\
\hline
\end{tabular}

In what follows, we employ the above indicators to gauge the relation between internationalization, GVC participation and firm's performance in terms of productivity. We use data on sales, value added and employment to compute sales per employee and value added per employee, and we estimate total factor productivity (TFP). Our TFP estimation assumes a Cobb-Douglas production function in which value added is the output variable. The estimation is performed at the country level as in Levinsohn

\footnotetext{
${ }^{9}$ Note that certification is costly and firms bear the cost only if they need to. To enter GVC certification is crucial.
} 
and Petrin (2003) ${ }^{10}$. Estimated TFP is highly positively correlated with the two other productivity measures as showed in Figure 12.

Figure 12: Total factor productivity and other productivity measures.
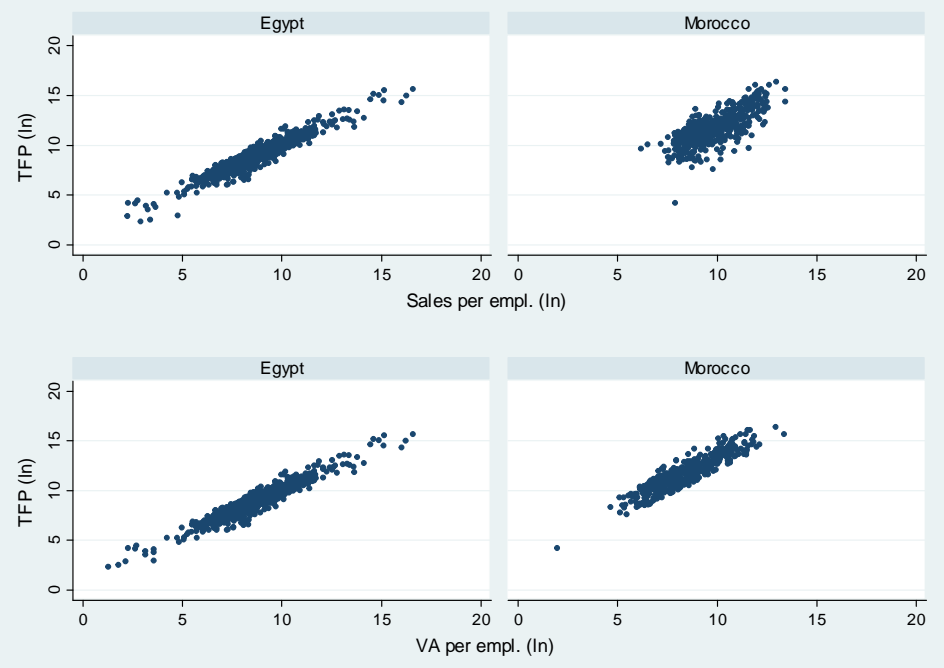

\subsection{Empirical analysis}

In our baseline equation we make use of the three different productivity measures as dependent variables, as follows:

$$
Y_{i, t}=\beta_{0}+\beta_{1} X_{i, t}+\beta_{2} G V C_{i, t}+\beta_{3} Z_{i, t}+\gamma_{c}+\gamma_{s}+\gamma_{t}+\varepsilon_{i, t}
$$

where $Y_{i t}$ is productivity (alternatively sales per worker, value added per worker or TFP) of firm $i$ in year $t$ (i.e. 2004 or 2007) active in core industry $s$ in country $c$; $X_{i t}$ is the firm's international trade mode (either importer, exporter and twoway trader), $G V C_{i}$ (1 if the firm is a trader and has an internationally-recognized quality certification) is our proxy for global value chain involvement and $Z_{i t}$ represents firm-level control measures, namely employment, capital intensity, human capital, age and a foreign ownership dummy variable ( 1 if $i$ is foreign owned). In addition, the $\gamma$ terms represent a full set of (country, industry and year) fixed effects, in order to take into account all possible differences in institutional environments combined with industrial composition recorded at the 2-digit level of disaggregation and other aspects related to the year of the analysis.

Estimation results from a pooled standard ordinary least squares (OLS) regression are reported in Table $4^{11}$.

Not surprisingly, there is a positive relation between international linkages and firm performance, as all types of traders have positive and significant coefficients for the whole set of performance indicators. These findings are in line with the theoretical predictions that only the most productive firms are able to sustain the higher sunk costs of internationalization (Antràs and Helpman, 2004). Further, there is evidence of a "pecking order", as firms active in multiple globalization modes and importers tend to have a higher performance than exporters, which in turn tend to be more productive than domestic firms (Tomiura, 2007; Kohler and Smolka, 2012).

Firms involved in GVCs (i.e. traders with an internationally recognized quality certification) present, in line with our expectations, a productivity premium, as the coefficient on GVC is always

\footnotetext{
${ }^{10}$ In particular, the number of observations is not sufficient to perform separate country-sector estimations. Moreover, no deflators were available. Alternative estimations based on pooled OLS and panel fixed effect regressions produce very similar results.

${ }^{11}$ Correlation matrices show no multicollinearity issues. The model is robust to the inclusion of each of the regressors separately.
} 
Table 4: Productivity and GVC (pooled OLS).

\begin{tabular}{|c|c|c|c|c|c|c|}
\hline & (1) & (2) & (3) & (4) & (5) & (6) \\
\hline & Sales/empl. & VA/empl. & TFP & Sales/empl. & VA/empl. & TFP \\
\hline Exporter & $\begin{array}{l}0.348^{* * *} \\
(2.120)\end{array}$ & $\begin{array}{l}0.308^{*} \\
(1.753)\end{array}$ & $\begin{array}{l}0.511^{* * * *} \\
(3.153)\end{array}$ & $\begin{array}{l}0.221 \\
(1.487)\end{array}$ & $\begin{array}{l}0.190 \\
(1.224)\end{array}$ & $\begin{array}{l}0.116 \\
(0.734)\end{array}$ \\
\hline Importer & $\begin{array}{l}0.870 * * * \\
(8.881)\end{array}$ & $\begin{array}{l}0.855 * * * \\
(8.054)\end{array}$ & $\begin{array}{l}1.242 * * * \\
(11.184)\end{array}$ & $\begin{array}{l}0.710^{* * * *} \\
(6.633)\end{array}$ & $\begin{array}{l}0.710^{* * *} \\
(6.086)\end{array}$ & $\begin{array}{l}0.718^{* * * *} \\
(6.028)\end{array}$ \\
\hline Twoway trader & $\begin{array}{l}0.271 * * * \\
(2.807)\end{array}$ & $\begin{array}{l}0.319 * * * \\
(3.005)\end{array}$ & $\begin{array}{l}1.056 * * * \\
(9.119)\end{array}$ & $\begin{array}{l}0.186 \\
(1.545)\end{array}$ & $\begin{array}{l}0.255^{*} \\
(1.894)\end{array}$ & $\begin{array}{l}0.156 \\
(1.131)\end{array}$ \\
\hline GVC & $\begin{array}{l}0.524 * * * \\
(4.231)\end{array}$ & $\begin{array}{l}0.577 * * * \\
(4.380)\end{array}$ & $\begin{array}{l}1.002 * * * \\
(7.468)\end{array}$ & $\begin{array}{l}0.398 * * * \\
(3.172)\end{array}$ & $\begin{array}{l}0.444 * * * \\
(3.389)\end{array}$ & $\begin{array}{l}0.539 * * * \\
(4.066)\end{array}$ \\
\hline FDI & & & & $\begin{array}{l}0.021 \\
(0.237)\end{array}$ & $\begin{array}{l}0.087 \\
(0.744)\end{array}$ & $\begin{array}{l}0.133 \\
(1.111)\end{array}$ \\
\hline Employment (ln) & & & & $\begin{array}{l}0.014 \\
(0.405)\end{array}$ & $\begin{array}{l}0.011 \\
(0.291)\end{array}$ & $\begin{array}{l}0.491^{* * * *} \\
(12.309)\end{array}$ \\
\hline Age & & & & $\begin{array}{l}0.000 \\
(0.060)\end{array}$ & $\begin{array}{l}0.000 \\
(0.066)\end{array}$ & $\begin{array}{l}0.001 \\
(0.564)\end{array}$ \\
\hline Human capital & & & & $\begin{array}{l}-0.019 \\
(-0.190)\end{array}$ & $\begin{array}{l}-0.025 \\
(-0.223)\end{array}$ & $\begin{array}{l}-0.026 \\
(-0.224)\end{array}$ \\
\hline Capital intensity (ln) & & & & $\begin{array}{l}0.272 * * * \\
(10.754)\end{array}$ & $\begin{array}{l}0.294 * * * \\
(10.976)\end{array}$ & $\begin{array}{l}0.007 \\
(0.240)\end{array}$ \\
\hline Constant & $\begin{array}{l}5.230 * * \\
(2.258)\end{array}$ & $\begin{array}{l}5.208 * * \\
(2.242)\end{array}$ & $\begin{array}{l}7.326 * * * \\
(4.246)\end{array}$ & $\begin{array}{l}5.523 * * * \\
(3.069)\end{array}$ & $\begin{array}{l}5.520^{* * * *} \\
(3.115)\end{array}$ & $\begin{array}{l}5.438 * * * \\
(3.243)\end{array}$ \\
\hline Country f.e. & Yes & Yes & Yes & Yes & Yes & Yes \\
\hline Sector f.e. & Yes & Yes & Yes & Yes & Yes & Yes \\
\hline Year f.e. & Yes & Yes & Yes & Yes & Yes & Yes \\
\hline Observations & 1802 & 1741 & 1708 & 1750 & 1694 & 1694 \\
\hline R-squared & 0.308 & 0.205 & 0.274 & 0.402 & 0.314 & 0.365 \\
\hline
\end{tabular}

$\mathrm{t}$ statistics in parentheses

$* \mathrm{p}<0.1, * * \mathrm{p}<0.05, * * * \mathrm{p}<0.01$

positive and significant at $1 \%$ level. Since quality certifications are a crucial requirement to enter international supply chains, this result corroborates our hypothesis that firms in GVC are more efficient and perform relatively better than other traders and dometic firms, a fact that seems of particular importance for developing and emerging countries.

Interestingly, foreign ownership is positively related to productivity only when we exclude other firm-level controls, showing that firms integrated in a multinational group perform relatively better with respect to their domestically owned counterparts (Blomström and Sjöholm, 1999); however, it becomes not significant when we also include other controls, such as employment, in the model, suggesting that, in our case, the main difference with domestically owned firms is primarily in the scale of the operation.

With the baseline results from a pooled OLS, we explicitly consider the time dimension of our data according to the following model:

$$
Y_{i, t}=\beta_{0}+\beta_{1} X_{i, t}+\beta_{2} G V C_{i, t}+Y_{i, t-1}+\beta_{3} Z_{i, t-1}+\gamma_{c}+\gamma_{s}+\gamma_{t}+\varepsilon_{i t}
$$

In Table 5, we test our specifications by including lags for the main control variables. First, we introduce the lagged dependent variables (Table 5, columns 1,2 and 3). Then, we also control for the the lagged values of employment, human capital and capital intensity (Table 5, columns 4,5 and 6). The main finding of our analysis, i.e. that involvement in GVCs is associated to higher performance of firms, is confirmed in all the cases.

Finally, as a robustness check, we examine whether the results hold in a quantile regression analysis, since OLS consider only the conditional mean response of productivity to a change in one of the explanatory variable. We therefore use quantile regression (QR) to estimate the parameters of the model at different points on the (conditional) productivity distribution. ${ }^{12}$ This is in line with Foster-

\footnotetext{
${ }^{12} \mathrm{QR}$ has a number of other advantages over OLS. One relates to the fact that median regression methods can be more efficient than mean regression estimators in the presence of heteroskedasticity. QR is also robust with regard to outlying observations in the dependent variable. The $\mathrm{QR}$ objective function is a weighted sum of absolute deviations,
} 
Table 5: Productivity and GVC (OLS with lags).

\begin{tabular}{|c|c|c|c|c|c|c|}
\hline & (1) & (2) & (3) & (4) & (5) & (6) \\
\hline & Sales/empl. & VA/empl. & TFP & Sales/empl. & VA/empl. & TFP \\
\hline Exporter & $\begin{array}{l}0.373 \\
(1.390)\end{array}$ & $\begin{array}{l}0.351 \\
(1.256)\end{array}$ & $\begin{array}{l}0.369 \\
(1.397)\end{array}$ & $\begin{array}{l}0.450 \\
(1.582)\end{array}$ & $\begin{array}{l}0.448 \\
(1.524)\end{array}$ & $\begin{array}{l}0.318 \\
(1.189)\end{array}$ \\
\hline Importer & $\begin{array}{l}0.454 * * * \\
(3.083)\end{array}$ & $\begin{array}{l}0.415^{* *} \\
(2.511)\end{array}$ & $\begin{array}{l}0.571 * * * \\
(3.263)\end{array}$ & $\begin{array}{l}0.384 * * \\
(2.360)\end{array}$ & $\begin{array}{l}0.347^{*} \\
(1.836)\end{array}$ & $\begin{array}{l}0.346^{*} \\
(1.864)\end{array}$ \\
\hline Twoway trader & $\begin{array}{l}0.076 \\
(0.538)\end{array}$ & $\begin{array}{l}0.059 \\
(0.357)\end{array}$ & $\begin{array}{l}0.515 * * * \\
(2.829)\end{array}$ & $\begin{array}{l}0.038 \\
(0.204)\end{array}$ & $\begin{array}{l}0.028 \\
(0.123)\end{array}$ & $\begin{array}{l}0.058 \\
(0.254)\end{array}$ \\
\hline GVC & $\begin{array}{l}0.490 * * * \\
(3.020)\end{array}$ & $\begin{array}{l}0.552^{* * * *} \\
(3.199)\end{array}$ & $\begin{array}{l}0.881 * * * \\
(4.781)\end{array}$ & $\begin{array}{l}0.405 * * \\
(2.251)\end{array}$ & $\begin{array}{l}0.470 \text { ** } \\
(2.435)\end{array}$ & $\begin{array}{l}0.534 * * * \\
(2.830)\end{array}$ \\
\hline L.Sales per empl. (ln) & $\begin{array}{l}0.246^{* * *} \\
(5.463)\end{array}$ & & & $\begin{array}{l}0.225^{* * *} \\
(4.501)\end{array}$ & & \\
\hline L.VA per empl. (ln) & & $\begin{array}{l}0.242 * * * \\
(5.263)\end{array}$ & & & $\begin{array}{l}0.212 \text { *** } \\
(4.219)\end{array}$ & \\
\hline L.TFP (ln) & & & $\begin{array}{l}0.308^{* * * *} \\
(6.437)\end{array}$ & & & $\begin{array}{l}0.208^{* * * *} \\
(4.683)\end{array}$ \\
\hline FDI & & & & $\begin{array}{l}0.203 \\
(1.478)\end{array}$ & $\begin{array}{l}0.071 \\
(0.350)\end{array}$ & $\begin{array}{l}0.054 \\
(0.276)\end{array}$ \\
\hline L.Employment (ln) & & & & $\begin{array}{l}0.027 \\
(0.456)\end{array}$ & $\begin{array}{l}0.019 \\
(0.256)\end{array}$ & $\begin{array}{l}0.348 * * * \\
(4.731)\end{array}$ \\
\hline L.Human capital & & & & $\begin{array}{l}0.092 \\
(0.646)\end{array}$ & $\begin{array}{l}0.184 \\
(1.099)\end{array}$ & $\begin{array}{l}0.342^{* *} \\
(2.076)\end{array}$ \\
\hline L.Capital intensity (ln) & & & & $\begin{array}{l}0.056^{*} \\
(1.772)\end{array}$ & $\begin{array}{l}0.069 * * \\
(2.095)\end{array}$ & $\begin{array}{l}0.103^{* * * *} \\
(3.301)\end{array}$ \\
\hline Age & & & & $\begin{array}{l}-0.001 \\
(-0.320)\end{array}$ & $\begin{array}{l}0.000 \\
(0.064)\end{array}$ & $\begin{array}{l}0.001 \\
(0.248)\end{array}$ \\
\hline Constant & $\begin{array}{l}-0.489 \\
(-1.073)\end{array}$ & $\begin{array}{l}-0.494 \\
(-1.071)\end{array}$ & $\begin{array}{l}1.513 * * * \\
(2.994)\end{array}$ & $\begin{array}{l}-0.583 \\
(-1.087)\end{array}$ & $\begin{array}{l}-0.551 \\
(-0.939)\end{array}$ & $\begin{array}{l}0.700 \\
(1.329)\end{array}$ \\
\hline Country f.e. & Yes & Yes & Yes & Yes & Yes & Yes \\
\hline Sector f.e. & Yes & Yes & Yes & Yes & Yes & Yes \\
\hline Year f.e. & Yes & Yes & Yes & Yes & Yes & Yes \\
\hline Observations & 878 & 825 & 794 & 847 & 798 & 789 \\
\hline R-squared & 0.372 & 0.247 & 0.343 & 0.380 & 0.261 & 0.387 \\
\hline
\end{tabular}

McGregor et al. (2014) which estimate different parameters on the trade dummies for under-achievers (i.e. those at the lower end of the conditional productivity distribution) and over-achievers (i.e. those at the upper end). For the sake of parsimony, we perform the $\mathrm{QR}$ on a simplified version of the previous model with lags in which we include the lagged values of the dependent variables and of employment, along with all the internationalization mode dummies and country fixed effects. Results from QR show that coefficients on the trade dummies are consistent with those from the OLS results as is the ranking in terms of the size of the coefficients. For space reasons, Figure 13 below only reports visual evidence of estimated coefficients for our variable of interest (i.e. GVC) (Azevedo, 2011). ${ }^{13}$ The reference line summarizes the simple least squares estimates. Narrow bands of $95 \%$ pointwise confidence intervals are reported for both quantiles and least squares specifications. A similar pattern emerges for all our productivity measures: QR coefficients are not statistically different from those obtained by mean of OLS, suggesting that in our case the positive effect of GVC participation applies similarly along the productivity spectrum.

which gives a robust measure of location, so that the estimated coefficient vector is not sensitive to outlier observations on the dependent variable. Finally, when the error term is non-normal, QR estimators may be more efficient than least squares estimators.

${ }^{13}$ The full regression table is available upon request. 
Figure 13: Quantile regression coefficients.
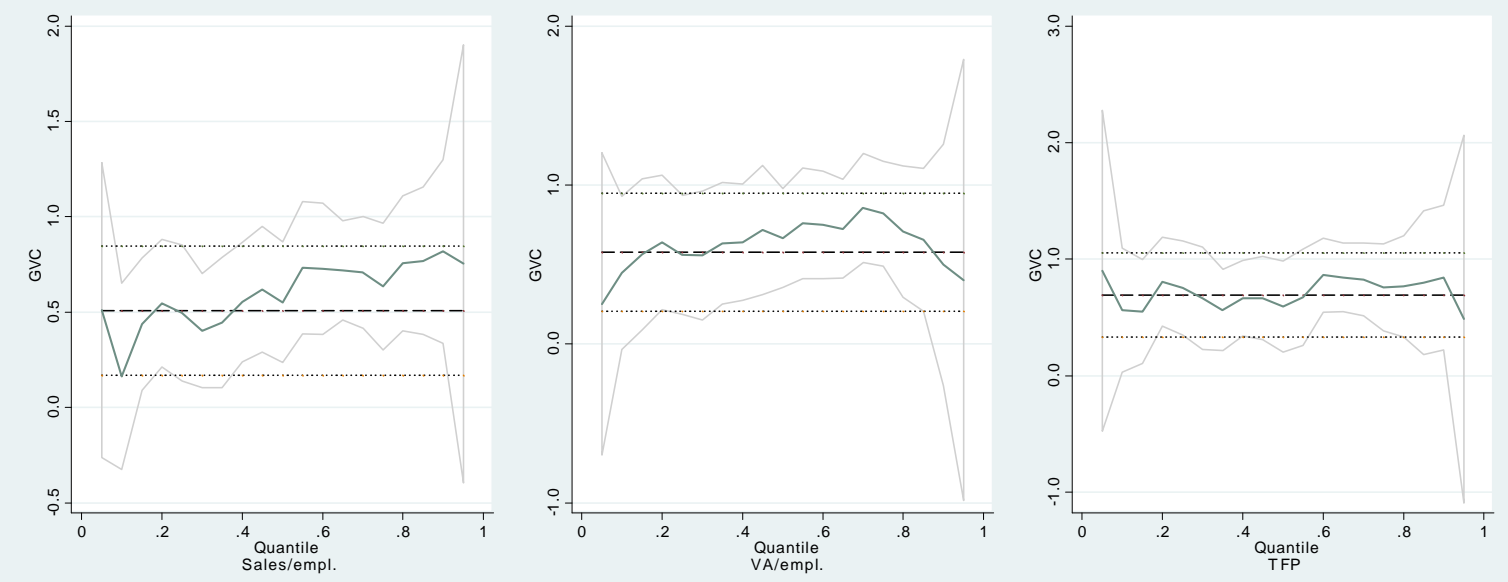

\section{Conclusions}

In this paper we investigate the impact of the involvement into GVCs for North African countries and firms, exploiting different datasets. Our results show that North Africa has not been able so far to fully enter into global production networks, being a very marginal player at the world level. Despite this, NA exports, although quantitatively low, largely and increasingly rely on GVC-related trade. Considering positioning along the GVC, NA mostly participates in the upstream phases, which typically involve low value added activities. However, the area is rather heterogeneous. Different countries are integrated in different ways, with very few successful examples of beneficial participation in a value chain.

Two main policy implications can be drawn from the analysis. Regardless of a firm's position in the value chain, minimum quality and reliability requirements must be met. The buyers' sourcing strategies are constantly revised to improve these elements of their supply chains. The complexity and heterogeneity of quality standards and certifications has become a large barrier, in particular for SMEs, adding a significant cost to trade. Upstream firms supplying intermediate inputs to several destinations may have to duplicate production processes to comply with conflicting standards, or to incur burdensome certification procedures multiple times for the same product. On this, international regulatory cooperation (convergence of standards, certification requirements and mutual recognition agreements) can alleviate the burden of compliance and enhance competitiveness.

Above all, for GVCs to have a positive impact on firms'productivity and country's competitiveness, an adequate preparation is required. Human capital development can be tailored to the needs of particular segments of the value chain; specialized skills are a prerequisite for involvement in high value added stages of the chains associated with industries such as information technology, electronics and pharmaceuticals. Policies designed to support education and technical training represent an important tool to increase the gains of global production.

When such conditions are met, then GVC can become an important mean for linking developing countries to global production and trade, potentially supporting export propensity for SMEs, with possible positive consequences on employment and eventually growth. 


\section{A Appendix}

To compute value added components we require a multi-region input-output (MRIO) table, which builds upon national IO tables by breaking down the use of products by origin. While the rows in a MRIO table indicate the use of gross output from a particular industry in a country, the columns provide information on the technology of production, as they indicate the amounts of intermediates needed for the production of the gross output whose use is then decomposed along the row. Building on this info, we can translate the MRIO table for multiple countries and industries into a standard I-O matrix form, expressed as:

$$
\begin{aligned}
& \mathbf{x}=\mathbf{z}+\mathbf{y} \\
& \mathbf{x}=\mathbf{A} \mathbf{x}+\mathbf{y} \\
& \mathbf{x}=(\mathbf{I}-\mathbf{A})^{-1} \mathbf{y}=\mathbf{L} \mathbf{y}
\end{aligned}
$$

where $\mathbf{x}$ represents the gross output $n \times 1$ vector of $n$ countries, $\mathbf{z}$ the total intermediate demand vector $(\mathbf{z}=\mathbf{Z} \mathbf{j}$, with $\mathbf{Z}$ being the intermediate demand matrix and, $\mathbf{j}$ an all-one vector $), \mathbf{y}$ the total final demand vector $(\mathbf{y}=\mathbf{Y} \mathbf{j}$, with $\mathbf{Y}$ being the final demand matrix $)$, I the identity matrix, $\mathbf{A}$ is the technical coefficient matrix and $\mathbf{L}$ is the Leontief inverse matrix. Total value added is obtained from the vector $\mathbf{w}=\mathbf{x}-\mathbf{Z}^{\prime} \mathbf{j}$ as the difference between gross output and intermediates use. To calculate value added trade, we start with the share of value added per unit of output by country (e.g. $v_{1}=w_{1} / x_{1}$ being the first element of the vector $\mathbf{v}$ ), combined with the Leontief inverse matrix $\mathbf{L}$ and aggregate exports by country as retrieved by the sum of the intermediates and final goods sold abroad (e.g. $e_{1}=\left(z_{1}-Z_{11}\right)+\left(y_{1}-Y_{11}\right)$ being the first element of the vector $\left.\mathbf{e}\right)$. The value added trade matrix can then be written as $\mathbf{T}^{\mathbf{v}}=\mathbf{V L E}$, that is:

$$
\left(\begin{array}{ccc}
T_{11}^{\mathbf{v}} & \cdots & T_{1 n}^{\mathbf{v}} \\
\vdots & \ddots & \vdots \\
T_{n 1}^{\mathbf{v}} & \cdots & T_{n n}^{\mathbf{v}}
\end{array}\right)=\left(\begin{array}{ccc}
v_{1} & \cdots & 0 \\
\vdots & \ddots & \vdots \\
0 & \cdots & v_{n}
\end{array}\right)\left(\begin{array}{ccc}
L_{11} & \cdots & L_{1 n} \\
\vdots & \ddots & \vdots \\
L_{n 1} & \cdots & L_{n n}
\end{array}\right)\left(\begin{array}{ccc}
e_{1} & \cdots & 0 \\
\vdots & \ddots & \vdots \\
0 & \cdots & e_{n}
\end{array}\right)
$$

where the left hand side matrix $\mathbf{T}^{\mathbf{v}}$ describes how the value added contained in the exports of each country (and industry) is generated (by column) and distributed (by row) across countries.

In fact, the columns of the matrix VL indicate the amount of value added required from the different row-countries for the column-country to produce 1 unit of gross output and all the columns sum up to 1 by construction.

Similarly, under the assumption of homogeneity between output and export, the columns of the matrix $\mathbf{T}^{\mathbf{v}}$ represents the value added content of exports of the column-country, which is then composed of two parts: on the main diagonal, the term $T_{i i}^{\mathbf{v}}$ denotes the Domestic Value Added (DVA) of country $i$; outside the main diagonal, the term $T_{k i}^{\mathbf{v}}=v_{k} L_{k i} e_{i}$ with $k \neq j$ denotes, instead, the Foreign Value Added (FVA) generated by row-country $k$ and incorporated in the exports of column-country $i$. The (column) sums of Domestic and Foreign Value Added, by construction, will yield the total exports of countries (i.e. $\mathbf{e}=\mathbf{T}^{\mathbf{v}} \mathbf{j}$ ).

The trade in value added $\mathbf{T}^{\mathbf{v}}$ matrix also provides information on how much of each country's domestic value added enters as an intermediate input in the value added exported by other countries. For row-country $i$, the term $T_{i k}^{\mathbf{v}}=v_{i} L_{i k} e_{k}$ represents exported domestic value added that is further incorporated into the exports of column-country $k$. Hence, by reading the matrix along the row (and excluding the diagonal term), it is possible to measure the "indirect value added exports" (DVX).

To capture the overall participation of countries and industries in GVCs we combine the FVA and DVX measures, by summing up the foreign value-added used in a country's own exports and the value added supplied to other countries' exports, and taking the sum as a ratio to gross exports, i.e. GVC $=\mathrm{FVA}+\mathrm{DVX}$. 


\section{B Table Appendix}

Figure 14: Common 25 ISIC-type classification.

\begin{tabular}{|c|c|}
\hline Sector name & ISIC Rev. 3 correspondence \\
\hline Agriculture & 1,2 \\
\hline Fishing & 5 \\
\hline Mining and quarrying & $10,11,12,13,14$ \\
\hline Food and beverages & 15,16 \\
\hline Textiles and wearing apparel & $17,18,19$ \\
\hline Wood and paper & $20,21,22$ \\
\hline Petroleum, chemical and non-metallic mineral products & $23,24,25,26$ \\
\hline Metal products & 27,28 \\
\hline Electrical and machinery & $29,30,31,32,33$ \\
\hline Transport equipment & 34,35 \\
\hline Other ma nufacturing & 36 \\
\hline Recycling & 37 \\
\hline Electricity, gas and water & 40,41 \\
\hline Construction & 45 \\
\hline Maintenance and repair & 50 \\
\hline Wholesale trade & 51 \\
\hline Retail trade & 52 \\
\hline Hotels and restaurants & 55 \\
\hline Transport & $60,61,62,63$ \\
\hline Post and telecommunications & 64 \\
\hline Financial intermediation and business activities & $65,66,67,70,71,72,73,74$ \\
\hline Public administration & 75 \\
\hline Education, health and other services & $80.85,90,91,92,93$ \\
\hline Private households & 95 \\
\hline Others & 99 \\
\hline
\end{tabular}


Figure 15: Algeria Sectoral GVC Participation (FVA + DVX) 2007

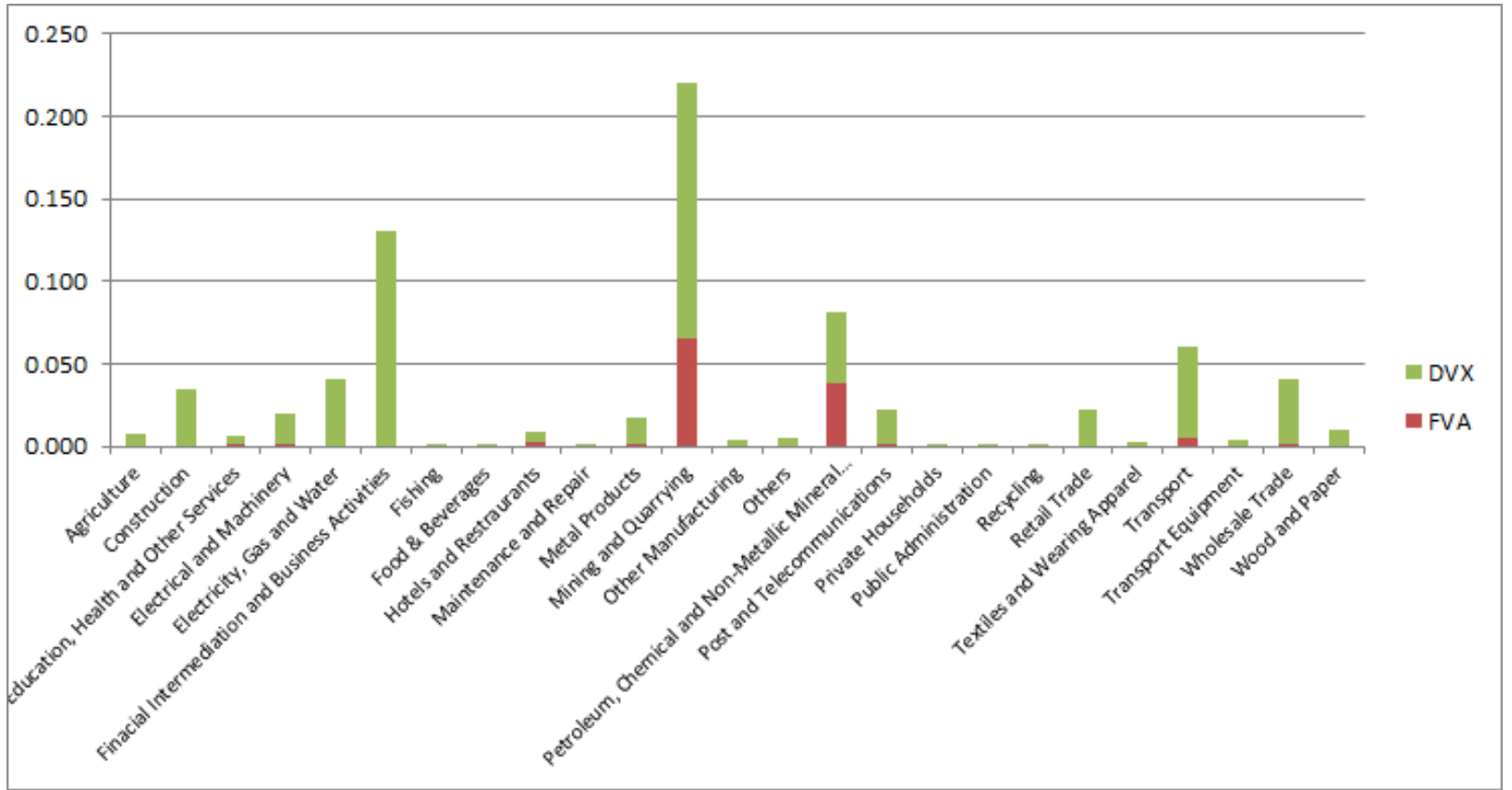

Source: Authors' elaboration based on UNCTAD/EORA GVC Database.

Figure 16: Libya Sectoral GVC Participation (FVA + DVX) 2007

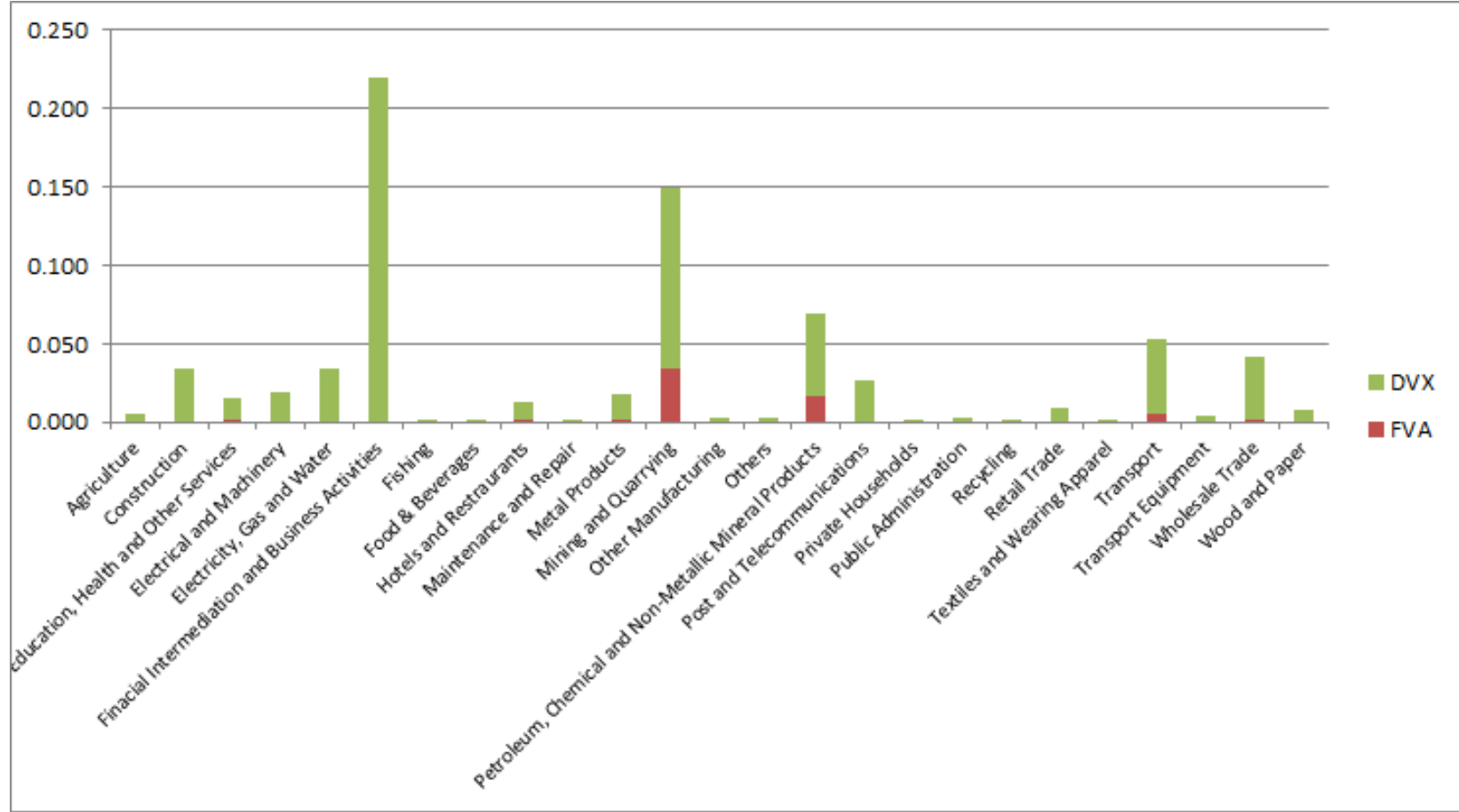

Source: Authors' elaboration based on UNCTAD/EORA GVC Database. 
Figure 17: Tunisia Sectoral GVC Participation (FVA + DVX) 2007

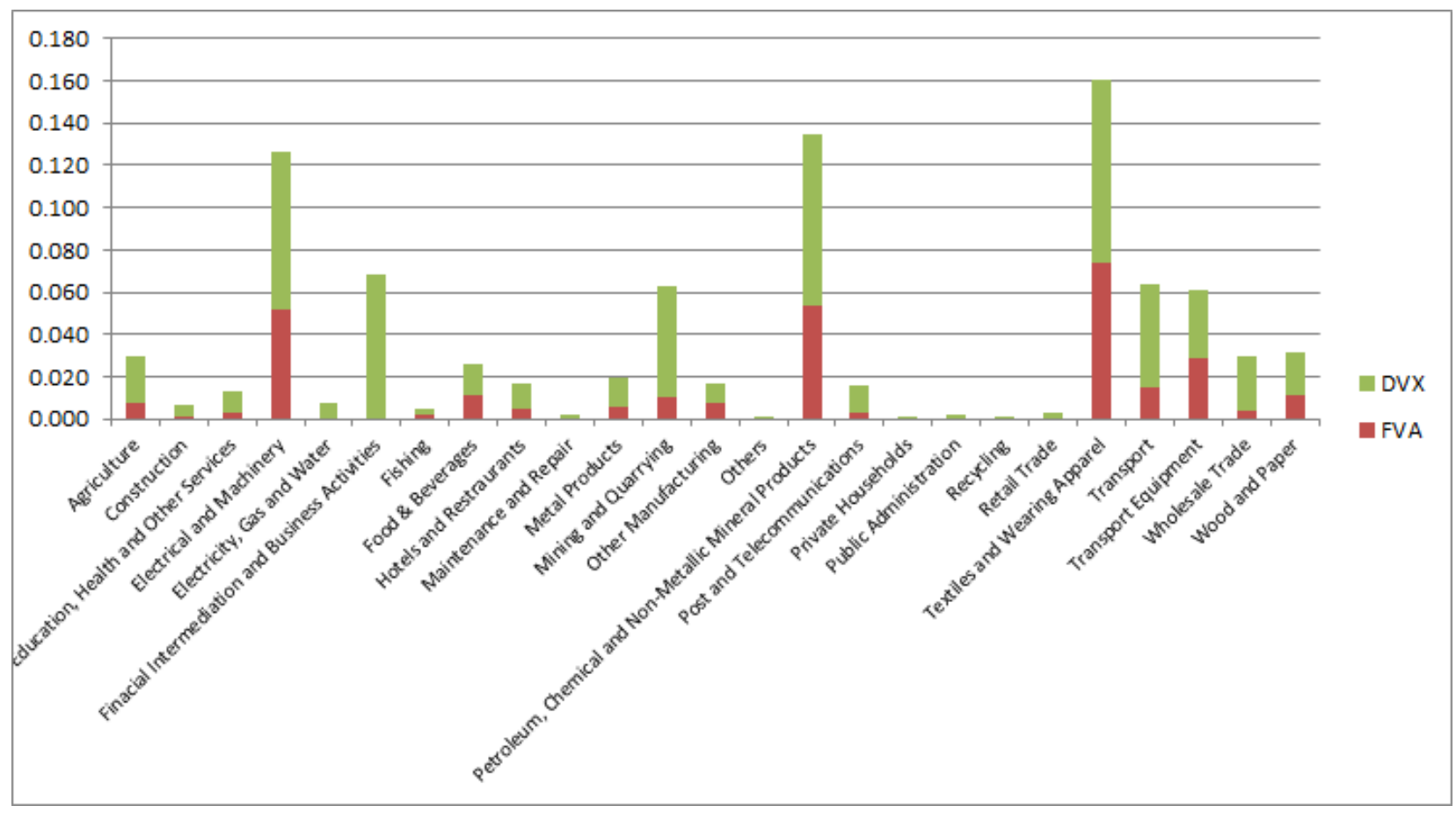

Source: Authors' elaboration based on UNCTAD/EORA GVC Database.

\section{References}

AfDB, OECD, UNDP, and UNECA (2014). "African Economic Outlook 2014". OECD Publishing Paris.

Agostino, M., A. Giunta, J. B. Nugent, D. Scalera, and F. Trivieri (2015). "The importance of being a capable supplier: Italian industrial firms in global value chains". International Small Business Journal 33(7), 708-730.

Alcacer, J. and J. Oxley (2014). "Learning by supplying". Strategic Management Journal 35(2), 204-223.

Antràs, P. and E. Helpman (2004). "Global Sourcing". Journal of Political Economy 112(3), 552-580.

Azevedo, J. (2011). "GRQREG: Stata module to graph the coefficients of a quantile regression.". Statistical Software Components.

Baldwin, R. and A. J. Venables (2013). "Spiders and snakes: Offshoring and agglomeration in the global economy". Journal of International Economics 90(2), 245-254.

Beghin, J., M. Maertens, and J. F. M. Swinnen (2015). "Non-Tariff Measures and Standards in Trade and Global Value Chains". Annual Review of Resource Economics $\%$.

Blomström, M. and F. Sjöholm (1999). "Technology transfer and spillovers: Does local participation with multinationals matter?". European Economic Review 43(4âĂŞ6), 915-923.

Cattaneo, O., G. Gereffi, and C. Staritz (2010). "Global value chains in a postcrisis world: a development perspective". World Bank Publications. 
Del Prete, D. and A. Rungi (2015). "Organizing the Global Value Chain: a firm-level test". EIC working paper series \#4/2015 IMT Institute for Advanced Studies Lucca ISSN 2279-6894.

Foster-McGregor, N., A. Isaksson, and F. Kaulich (2014). "Importing, exporting and performance in sub-Saharan African manufacturing firms". Review of World Economics 150(2), 309-336.

Foster-McGregor, N., F. Kaulich, and R. Stehrer (2015). "Global Value Chains in Africa". UNUMERIT Working Paper Series (024).

Gereffi, G. (1994). "The organization of buyer-driven global commodity chains: how US retailers shape overseas production networks". Contributions in Economics and Economic History, 95.

Giovannetti, G., E. Marvasi, and M. Sanfilippo (2015). "Supply chains and the internationalization of small firms". Small Business Economics 44(4), 845-865.

Humphrey, J. and H. Schmitz (2002). "How does insertion in global value chains affect upgrading in industrial clusters?". Regional studies 36(9), 1017-1027.

Johnson, R. C. and G. Noguera (2012). "Accounting for intermediates: Production sharing and trade in value added". Journal of International Economics 86(2), 224-236.

Kohler, W. K. and M. Smolka (2012). "Global Sourcing: Evidence from Spanish Firm-Level Data". In Quantitative Analysis of Newly Evolving Patterns of International Trade, Volume Volume 18 of World Scientific Studies in International Economics, pp. 139-193. WORLD SCIENTIFIC.

Koopman, R., Z. Wang, and S.-J. Wei (2011). "Give credit where credit is due: Tracing value added in global production chains". NBER Working Paper (16426).

Lenzen, M., K. Kanemoto, D. Moran, and A. Geschke (2012, aug). "Mapping the Structure of the World Economy". Environmental Science 83 Technology 46(15), 8374-8381.

Lenzen, M., D. Moran, K. Kanemoto, and A. Geschke (2013, mar). "Building Eora: A Global Multi-regional Input-Output Database at High Country and Sector Resolution". Economic Systems Research 25(1), 20-49.

Levinsohn, J. and A. Petrin (2003). "Estimating production functions using inputs to control for unobservables". The Review of Economic Studies 70(2), 317-341.

Marvasi, E. (2013). "The Sophistication of China's Exports, Imports and Intermediate Products". In G. Gomel, D. Marconi, I. Musu, and B. Quintieri (Eds.), The Chinese Economy, pp. 181-209. Berlin, Heidelberg: Springer Berlin Heidelberg.

OECD and WTO (2012). "Trade in Value-Added: Concepts, Methodologies, and Challenges". Paris: Organisation for Economic Co-operation and Development; and Geneva: World Trade Organization.

Timmer, M. P., E. Dietzenbacher, B. Los, R. Stehrer, and G. J. de Vries (2015, aug). "An Illustrated User Guide to the World Input-Output Database: the Case of Global Automotive Production". Review of International Economics 23(3), 575-605.

Tomiura, E. (2007). "Foreign outsourcing, exporting, and FDI: A productivity comparison at the firm level". Journal of International Economics 72(1), 113-127.

UNCTAD (2013). "World Investment Report". Geneva. 